\title{
Review of Urban Bicyclists' Intake and Uptake of Traffic-Related Air Pollution
}

\author{
ALEXANDER Y. BIGAZZI ${ }^{\S}$ AND MIGUEL A. FIGLIOZZI \\ Department of Civil and Environmental Engineering, Portland State University, PO Box 751, \\ Portland, OR 97232, USA
}

(Received 28 October 2013; revised 12 February 2014; accepted 20 February 2014)

\begin{abstract}
Bicycling as a mode of transportation is enjoying a boost in many urban areas around the world. Although there are clear health benefits of increased physical activity while bicycling, bicyclists may experience increased inhalation of traffic-related air pollutants. Bicyclists have two to five times higher respiration rates than travelers in motorized vehicles and this difference increases with bicycle travel speed and exertion level. The main goal of this work is to review the state of knowledge regarding urban bicyclists' intake and uptake of traffic-related air pollution and to identify key knowledge gaps. This review includes not only bicyclists' exposure to air pollution concentrations but also respiration rates, intake doses (the amount of pollutant that is inhaled), and uptake doses (the amount of pollutant that is incorporated into the body). Research gaps and opportunities for future research are discussed. This is the first review to specifically address bicyclists' health risks from traffic-related air pollution and to explicitly include intake and uptake doses in addition to exposure concentrations for travelers.
\end{abstract}

\section{Introduction}

Bicycling as a mode of transportation is enjoying a boost in urban areas around the world through new bike-sharing systems, bicycle-specific roadway facilities, public outreach, and incentive programs (Pucher \& Buehler, 2012). The push toward promoting bicycling is motivated by a range of environmental, economic, health, and social benefits. Although there are clear health benefits of increased physical activity, bicyclists may experience increased inhalation of traffic-related air pollutants (de Hartog, Boogaard, Nijland, \& Hoek, 2010).

Human exposure to traffic-related air pollution has well-established negative health impacts for urban populations (Brook et al., 2010; Forastiere \& Agabiti, 2013; Health Effects Institute, 2010; Nawrot et al., 2011). Air pollution exposure is particularly high for travelers because of proximity to mobile sources of pollution (Kaur, Nieuwenhuijsen, \& Colvile, 2007), and air quality is a source of concern for urban bicyclists (Badland \& Duncan, 2009). However, the health risks of air pollution exposure during travel are not easily characterized because of the numerous individual, environmental, and traffic factors involved.

${ }^{8}$ Corresponding author. Email: abigazzi@pdx.edu

(C) 2014 Taylor \& Francis 
A conceptual diagram linking traffic-related pollution emissions and health effects is illustrated in Figure 1, adapted from Ott, Steinemann, and Wallace (2007). Motor vehicle emissions (a) degrade urban air quality (b) in accordance with atmospheric dispersive, chemical, and physical processes. Travelers' exposure concentrations (c) then depend on their travel trajectory. The inhalation of traffic-related air pollution (d) depends on travelers' breathing volume while exposed to a pollutant concentration. Uptake of the inhaled pollutants into the body (e) depends on processes in the respiratory tract and other body systems. Finally, the health effects (f) of air pollution uptake doses are a function of the toxicity of the pollutants and physiology of the individual. The processes between inhalation and uptake can be further demarcated as $\left(\mathrm{e}_{1}\right)$ intake dose (the amount of pollutant that crosses the body boundary at the mouth and nose), $\left(e_{2}\right)$ absorbed dose (the amount of pollutant that is not exhaled but deposited or absorbed), $\left(e_{3}\right)$ effective dose (the bioavailable amount of pollutant that reaches body tissue instead of being expelled from the respiratory tract lining by coughing, sneezing, etc.), and $\left(\mathrm{e}_{4}\right)$ uptake dose (the amount of pollutant that is incorporated into the body).

Past reviews of travelers' pollution exposure have been oriented by pollutant (Kaur et al., 2007; Knibbs, Cole-Hunter, \& Morawska, 2011) and/or focused on in-vehicle exposures (El-Fadel \& Abi-Esber, 2009). These reviews focused on exposure concentrations and provide little or no discussion of respiration or its effects on intake and uptake doses. The focus of this review is on bicyclists' exposure to, inhalation of, and uptake of traffic-related air pollution - i.e. steps (c) through (f) in Figure 1. This review is unique in focusing exclusively on bicyclists.

\section{Methodology}

A systematic literature search for bicyclist exposure and dose measurements was performed through January 2014 using all 20 possible keyword combinations $\{A+B+C\}$ utilizing the keyword sets $A=\{$ bicycle, bicyclist, cyclist,

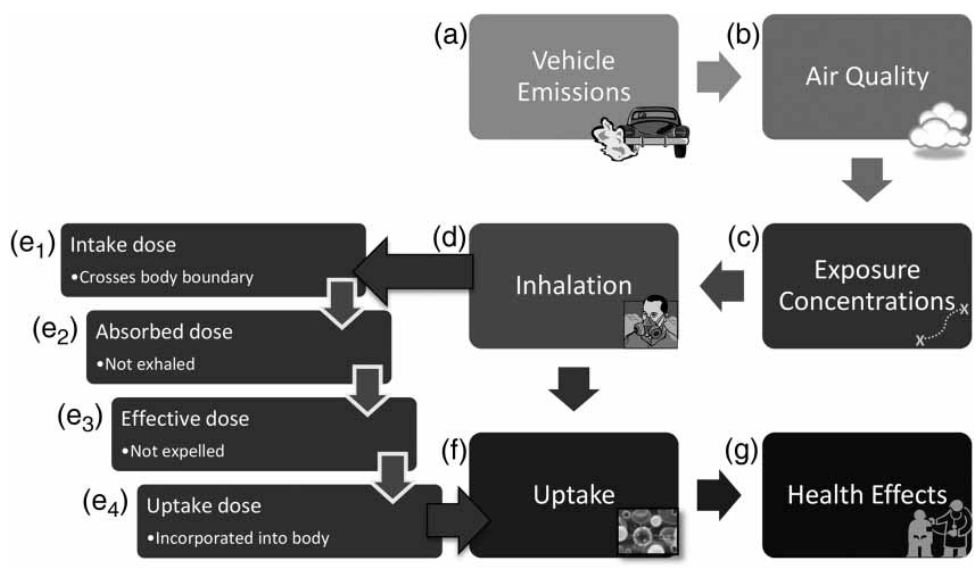

Figure 1. Conceptual diagram of exposure pathway for traffic-related air pollution. Source: Adapted from Ott, Stieneman, and Wallace (2007) 
bike $\}, B=$ \{pollution $\}$ and $C=$ exposure, intake, inhalation, uptake, dose $\}$. An exhaustive search was performed using the WorldCat ${ }^{\mathrm{TM}}$ catalog. Additional references were found by reviewing cited reference lists and the Google Scholar ${ }^{\mathrm{TM}}$ search engine. There were 57 published papers describing original studies of on-road bicyclists and air pollution exposures with spatially explicit concentration data. There were 42 published papers with unique exposure concentration data measured on road by bicyclists. Details of the literature search method are presented in the Supplemental Material.

\section{Bicyclists' Air Pollution Exposure Concentrations}

The main traffic-related air pollutants linked to health risks for road travelers and measured for bicyclists are carbon monoxide $(\mathrm{CO})$, nitrogen oxides $\left(\mathrm{NO}_{x}\right)$ including nitric oxide (NO) and nitrogen dioxide $\left(\mathrm{NO}_{2}\right)$, volatile organic compounds (VOC), and particulate matter (PM) of various sizes and composition: ultrafine particles (UFP), $\mathrm{PM}_{2.5}, \mathrm{PM}_{10}$, and elemental carbon (EC)/black carbon (BC). These pollutants are described in the Supplemental Material.

A traveler's exposure concentration is the concentration of pollutants in their breathing zone. Concentrations of traffic-related primary pollutants are particularly high near roadways - especially for shorter lived pollutants such as UFP and reactive VOC (Gordon et al., 2012; Karner, Eisinger, \& Niemeier, 2010). Steep concentration gradients can be seen even on the scale of a few meters (Clifford, Clarke, \& Riffat, 1997; McNabola, Broderick, \& Gill, 2009b; Tiwary, Robins, Namdeo, \& Bell, 2011). Exposure concentrations are sampled using a variety of pollutant-specific devices, each requiring specialized knowledge and careful sampling procedures (Vallero, 2008). Roadside studies of air pollution concentrations are more common than on-road data collections because on-road measurements are more difficult to execute (particularly for pedestrians and bicyclists). But the body of research on active travelers' pollution exposure concentrations has grown notably in recent years. On-road air quality sampling has become more precise and more portable because of improvements in measurement technology, power storage, and position tracking systems (Gulliver \& Briggs, 2004; Steinle, Reis, \& Sabel, 2013).

A literature search revealed 42 published studies reporting unique exposure concentration data collected with on-bicycle sampling devices. Summary information on all 42 studies is included in the Supplemental Material, allowing comparisons of methodologies and settings. Table 1 summarizes reported concentrations in all 42 studies, excluding results for 'rural' settings). Ranges of reported central value statistics and disaggregate (sample-level) values are presented, including the country where the low and high measurements were taken.

The mean on-road measurements in Table 1 are all well above typical urban background concentrations (see Supplemental Material). Table 1 shows that measured bicyclist exposure concentrations for most pollutants exhibit high variability among studies, with a standard deviation (SD) greater than $50 \%$ of the mean value for all pollutants except $\mathrm{PM}_{10}$, and a $\mathrm{SD}$ greater than the mean for $\mathrm{CO}$, benzene, and BC/EC. Bicyclists' average CO exposure concentrations have been measured in the range of $0.5-13$ ppm, though all studies after 1995 report central value concentrations below 3 ppm. 
Table 1. Summary of the 42 studies directly measuring on-road bicyclists' exposure concentrations

\begin{tabular}{|c|c|c|c|c|c|c|c|c|c|}
\hline \multirow[b]{2}{*}{ Pollutant } & \multirow[b]{2}{*}{ Units $^{\mathrm{a}}$} & \multirow[b]{2}{*}{ No. of studies $(N)^{\mathrm{b}}$} & \multirow[b]{2}{*}{ Years of studies } & \multicolumn{4}{|c|}{ Reported central values $^{c}$} & \multicolumn{2}{|c|}{ Reported disaggregate values } \\
\hline & & & & Mean (SD) & Median & Low & High & Low & High \\
\hline $\mathrm{CO}$ & ppm & $12(16)$ & 1976-2013 & $2.8(3.9)$ & 1.2 & 0.5 (New Zealand) & 13 (USA) & 0.1 (New Zealand) & 21 (USA) \\
\hline $\mathrm{NO}_{2}$ & $\mu \mathrm{g} / \mathrm{m}^{3}$ & $4(5)$ & $1995-2006$ & $55.8(33.8)$ & 46.3 & 26 (Australia) & 114 (Netherlands) & 8 (Australia) & 262 (the Netherlands) \\
\hline $\mathrm{VOC}^{\mathrm{d}}$ & & 9 & $1991-2011$ & & & & & & \\
\hline Benzene & $\mu \mathrm{g} / \mathrm{m}^{3}$ & $9(12)$ & $1991-2011$ & $17.2(18.3)$ & 10.6 & 0.34 (Canada) & 56 (UK) & 0.1 (Canada) & 120 (UK) \\
\hline Toluene & $\mu \mathrm{g} / \mathrm{m}^{3}$ & $6(7)$ & $1991-2011$ & $57.6(51.6)$ & 50.5 & 1.07 (Canada) & $122(\mathrm{UK})$ & 0.3 (Canada) & 1230 (Italy) \\
\hline Xylenes & $\mu \mathrm{g} / \mathrm{m}^{3}$ & $5(6)$ & $1991-2011$ & $48.9(45.2)$ & 44.3 & 0.6 (Canada) & 105 (Italy) & 0.15 (Canada) & 281 (Italy) \\
\hline \multicolumn{10}{|l|}{$\mathrm{PM}^{\mathrm{e}}$} \\
\hline UFP, PNC & $\mathrm{pt} / \mathrm{cc}$ & $18(31)$ & $2005-13$ & $28450(18$ 169) & 24800 & 8734 (Belgium) & 93968 (UK) & 1900 (USA) & 1033188 (USA) \\
\hline $\mathrm{PM}_{2.5}$ & $\mu \mathrm{g} / \mathrm{m}^{3}$ & $17(29)$ & $2001-14$ & $29.9(22.8)$ & 23.5 & 4.88 (USA) & 88.1 (Ireland) & 0 (the Netherlands) & $130(\mathrm{UK})$ \\
\hline $\mathrm{PM}_{10}$ & $\mu \mathrm{g} / \mathrm{m}^{3}$ & $10(15)$ & $2001-14$ & $50.2(12.0)$ & 50.0 & 32.0 (New Zealand) & 72.7 (Belgium) & 8.2 (New Zealand) & 160 (Belgium) \\
\hline $\mathrm{BC}, \mathrm{EC}^{\mathrm{f}}$ & $\mu \mathrm{g} / \mathrm{m}^{3}$ & $9(14)$ & $2002-13$ & $6.85(7.09)$ & 3.04 & 1.05 (Canada) & $21.0(\mathrm{UK})$ & 0.09 (USA) & 63.83 (USA) \\
\hline
\end{tabular}

${ }^{\mathrm{a} C}$ Conversion of reported values between $\mu \mathrm{g} / \mathrm{m}^{3}$ and $\mathrm{ppb}$ or ppm assumes molar gas volume of $24.45 \mathrm{~L}$.

bSome studies report separate central value results by route. All routes are included except those designated as 'rural' settings. See Supplemental Material for details.

${ }^{c}$ When multiple central value statistics are reported in a study, a single value was selected as the arithmetic mean, geometric mean, or median, in that order.

${ }^{\mathrm{d}}$ Various compounds are reported in the studies measuring VOC; only benzene, toluene, and $\left(0-, m_{-}\right.$, and $\left.p-\right)$ xylenes are reported in more than half of the VOC studies.

' In addition to BC, UFP, $\mathrm{PM}_{2.5}$, and $\mathrm{PM}_{10}$, six studies report PM of other sizes $\left(\mathrm{PM}_{1}\right.$ through $\left.\mathrm{PM}_{5}\right)$ over the years $1991-2013$.

${ }^{\mathrm{f}}$ Excludes three additional studies that only report BC concentrations in units of absorbance. 


\subsection{Modal Comparisons of Exposure Concentration}

A popular study design for traveler exposure studies is modal comparisons, in which exposure concentrations are compared for travelers using different transportation modes between the same origin and destination or along identical or parallel routes. Results from modal comparisons of exposure are inconsistent. Bicyclists sometimes have lower exposure concentrations than motorized modes, especially when they use facilities that are separated from traffic (Adams, Nieuwenhuijsen, \& Colvile, 2001; Adams, Nieuwenhuijsen, Colvile, Older, \& Kendall, 2002; Boogaard, Borgman, Kamminga, \& Hoek, 2009; Chertok, Voukelatos, Sheppeard, \& Rissel, 2004; De Nazelle et al., 2012; Dons, Int Panis, Van Poppel, Theunis, \& Wets, 2012; Kaur et al., 2007; Kingham, Longley, Salmond, Pattinson, \& Shrestha, 2013; Kingham, Meaton, Sheard, \& Lawrenson, 1998; Knibbs et al., 2011; McNabola, Broderick, \& Gill, 2008; van Wijnen, Verhoeff, Jans, \& Bruggen, 1995). But modal comparison studies have also found insignificant differences in concentrations by mode, significantly higher bicyclist exposure concentrations than other modes, or inconsistent results by pollutant, location, or time of day (Boogaard et al., 2009; Chertok et al., 2004; De Nazelle et al., 2012; Int Panis et al., 2010; Kaur \& Nieuwenhuijsen, 2009; Kingham et al., 2013; Nwokoro et al., 2012; Quiros, Lee, Wang, \& Zhu, 2013; Ragettli et al., 2013; Waldman, Weiss, \& Articola, 1977; Yu et al., 2012). Likely causes of inconsistent results across studies include differences in the proximity and intensity of motor vehicle traffic, varying availability and use of bicycle facilities, and instrumentation/sampling differences (see Supplemental Material for information on study methods).

Modal comparison exposure studies typically use the same routes or origins and destinations across modes and fix other travel characteristics (e.g. departure time). While potentially informative, these comparisons are not always realistic because pollution exposure is also affected by intrinsic modal travel differences. The more realistic modal comparisons allow self-selected routes or direct active travelers to use representative routes for their mode - but local transportation network characteristics may affect the results. Bicycle travel patterns are different from motorized ones because of distinct traveler characteristics, trip distances, and route preferences (Broach, Dill, \& Gliebe, 2012; Plaut, 2005). Real-world bicycle trips tend to be shorter and in higher density parts of a city than trips using motorized modes. Bicycle trips are also highly seasonal (Nankervis, 1999), so a different distribution of meteorological conditions could be expected by mode, with a systematic influence on exposure concentrations. Most bicycle exposure studies occur during warmer months when a greater proportion of bicycling occurs (see the Supplemental Material), but the joint seasonality of mode splits and pollution levels should be considered when comparing travelers' exposures - especially for year-round bicyclists.

Although modal comparisons can be informative, they rarely provide practical insights into how to reduce exposure concentrations, other than mode shifts. Modal comparison studies rarely vary within mode factors (such as route choice), which can be the most important determinants of exposure concentrations during travel (Knibbs et al., 2011).

\subsection{Factors Affecting Bicyclists' Exposure Concentrations}

Multivariate analyses of travelers' exposure concentrations have shown that important factors include wind and weather, traffic and route, and the built environment around the roadway (Adams, Nieuwenhuijsen, \& Colvile, 2001; 
Berghmans et al., 2009; Boogaard et al., 2009; Hatzopoulou, Weichenthal, Dugum, et al., 2013; Kaur \& Nieuwenhuijsen, 2009; Kaur et al., 2007; Knibbs et al., 2011; McNabola, Broderick, \& Gill, 2009a; Quiros et al., 2013). But few studies have looked at bicyclist-specific factors that could influence exposure, such as lateral position in the road, proximity to exhaust pipes, breathing height, and the ability to 'dodge between' vehicles (Kaur et al., 2007).

Wind is consistently a significant factor for exposure, decreasing concentrations through dispersion (Adams, Nieuwenhuijsen, \& Colvile, 2001; Hatzopoulou, Weichenthal, Dugum, et al., 2013; Hong \& Bae, 2012; Jarjour et al., 2013; Kaur \& Nieuwenhuijsen, 2009; Kaur et al., 2007; Kingham et al., 1998; Knibbs et al., 2011; McNabola et al., 2009a). Temperature is less consistently a significant factor, and effects can be difficult to distinguish from humidity because of a strong negative correlation (Adams, Nieuwenhuijsen, \& Colvile, 2001; Hatzopoulou, Weichenthal, Dugum, et al., 2013; Kaur \& Nieuwenhuijsen, 2009; Kaur et al., 2007; Kingham et al., 1998; Knibbs et al., 2011). Time of day is a factor that incorporates influencing effects of local weather and diurnal traffic patterns - particularly relevant for urban areas with diurnal temperature inversions that significantly affect pollutant levels.

After weather, the next most important factors for bicyclists' exposure concentrations can be combined into a single category: separation from motor vehicle traffic. These factors include the concentration-reducing effects of traveling on low-traffic routes (Hatzopoulou, Weichenthal, Dugum, et al., 2013; Hertel, Hvidberg, Ketzel, Storm, \& Stausgaard, 2008), on separated bicycle facilities (Hatzopoulou, Weichenthal, Dugum, et al., 2013; Hong \& Bae, 2012; Kendrick et al., 2011; Kingham et al., 2013, 1998), and during off-peak periods or weekends (Dons et al., 2013; Huang, Deng, Wu, \& Guo, 2012; Kleiner \& Spengler, 1976). Lacking more specific data, the influence of motor vehicle traffic on exposure concentrations is sometimes estimated using a proxy of facility type, time-of-day, or average daily traffic (ADT) estimates (Boogaard et al., 2009; Cole-Hunter, Morawska, Stewart, Jayaratne, \& Solomon, 2012; Hong \& Bae, 2012; Jarjour et al., 2013; Ragettli et al., 2013; Weichenthal et al., 2011).

The influence of motor vehicle traffic was measured in 14 different studies by comparing bicyclists' exposure concentrations on 'high-traffic' and 'low-traffic' routes or using a related dichotomy (inner-city/suburban, on-road/off-road, near-road/cycle path). The combined results are shown in Figure 2, with the median and range of reported percent increases on 'high-traffic' versus 'lowtraffic' routes (see the Supplemental Material for sources). As expected, pollutants that are more dominated by motor vehicle sources in roadway environments (hydrocarbon VOC, UFP) show larger increases on high-traffic routes.

Explicit traffic variables such as motor vehicle volume or speed are often not included in bicyclist pollution exposure analysis because of a lack of concomitant data. When assessed, vehicle volumes, particularly truck or diesel vehicles, generally have a positive influence on pollutant exposure concentrations, though they are not always significant variables (Boogaard et al., 2009; Dons et al., 2013; Hatzopoulou, Weichenthal, Dugum, et al., 2013; Kaur \& Nieuwenhuijsen, 2009; Knibbs et al., 2011; McNabola et al., 2009a; Quiros et al., 2013). Aggregate traffic variables such as ADT cannot reveal the potentially important influences of varying traffic volumes, speeds, queuing, and fleet composition over the data collection periods. Furthermore, highly aggregate traffic variables are often correlated with geometric roadway characteristics such as the number of lanes, which also influence pollutant concentrations through dispersion. 


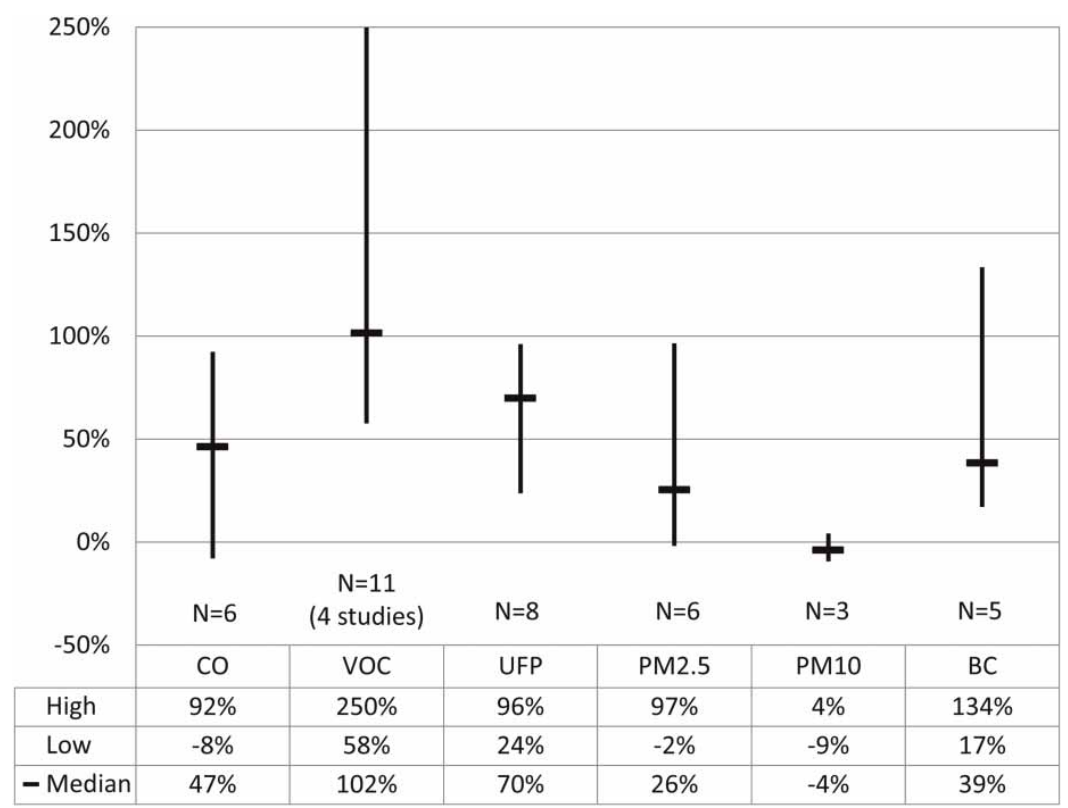

Figure 2. Reported increases in bicyclists' exposure concentrations in 'high-traffic' versus 'low-traffic' routes and locations.

Notes: Urban/rural comparisons are excluded. Where multiple observations are reported per study (e.g. by city or time period), a weighted average by number of samples was used. For VOC, reported BTEX compounds (benzene, toluene, ethylbenzene, and xylenes) are included (11 comparisons for these compounds in different studies).

Sources: CO (Bevan, Proctor, Baker-Rogers, \& Warren, 1991; Jarjour et al., 2013; Kingham et al., 2013; Kleiner and Spengler, 1976; Waldman et al., 1977; Weichenthal et al., 2011), VOC (Bevan et al., 1991; Kingham et al., 1998; McNabola et al., 2008; Weichenthal et al., 2011), UFP (Cole-Hunter et al., 2012, 2013; Jarjour et al., 2013; Kingham et al., 2013; Ragettli et al., 2013; Strak et al., 2010; Weichenthal et al., 2011; Zuurbier et al., 2010), PM2.5 (Adams, Nieuwenhuijsen, Colvile, McMullen, \& Khandelwal, 2001; Jarjour et al., 2013; Kingham et al., 2013; McNabola et al., 2008; Weichenthal et al., 2011; Zuurbier et al., 2010), PM10 (Kingham et al., 2013; Strak et al., 2010; Zuurbier et al., 2010), BC (Jarjour et al., 2013; Kingham et al., 1998; Strak et al., 2010; Weichenthal et al., 2011; Zuurbier et al., 2010)

Traffic data used in bicycle exposure studies to date have been non-specific to the study period, limited in spatial and temporal coverage, and/or highly aggregated (in time and vehicle type). Of the 42 studies included in Table 1, only 4 report traffic data collected at the locations and time periods of air quality measurements. Kaur, Nieuwenhuijsen, and Colvile (2005) ${ }^{1}$ and McNabola et al. $(2008)^{2}$ retrieved unclassified hourly vehicle volumes from traffic signal data at major intersections on the study routes. Hatzopoulou, Weichenthal, Dugum, et al. (2013) collected intermittent manual vehicle counts using five vehicle classes for 10-20 min periods sequentially at dozens of locations around the onroad measurement area. Quiros et al. (2013) performed intermittent manual vehicle counts for 5 min periods using nine vehicle classes (including bicycles and pedestrians) at a single location on the study corridor.

The next major factors for exposure concentrations, after weather and motor vehicle traffic, are the study setting and methodology. Comparing measured exposure concentrations across studies reveals wide ranges (Table 1), indicative of different study settings (time frame, city, and locational characteristics) and different experimental methods (instruments, sampling strategy, aggregation, 
etc.). Potentially important differences among study settings include traffic patterns, weather conditions, vehicle fleets and fuels, urban form, and topography. Boogaard et al. (2009) compare bicyclists' on-road exposure concentrations in 11 Dutch cities over a three-month period (using a consistent methodology) and report coefficients of variability for UFP and $\mathrm{PM}_{2.5}$ of 0.22 and 0.86 among cities. For comparison, the coefficients of variability for UFP and $\mathrm{PM}_{2.5}$ among studies in Table 1 are 0.64 and 0.76 .

\section{Bicyclists' Air Pollution Intake}

The mass of air pollutants that cross the body boundary through the mouth and nose is the intake dose (Ott et al., 2007). Estimates of intake dose rates per unit time combine exposure concentrations with a respiration rate; intake dose rates per unit distance also take travel duration into account (as does total intake dose over a journey). Some studies consider only duration (not respiration) by estimating cumulative exposure, such as Nwokoro et al. (2012) and Ragettli et al. (2013). Measurement and analysis of bicyclists' pollutant intake facilitates a transition toward a dose-oriented estimation of health effects.

\subsection{Respiration}

Respiration rate is commonly expressed as the minute respiratory volume (or minute ventilation, $V_{\mathrm{E}}$ ) - which is the volume of air displaced per minute. Minute respiratory volume is the product of the tidal volume $V_{\mathrm{T}}$ and the breathing frequency $f_{\mathrm{r}}$ (breaths per minute). Tidal volume $V_{\mathrm{T}}$ is the volume of air displaced in a single breath; typical ranges are 1.4-2.2 L for bicyclists and 0.6-0.8 L for persons at rest or in a car (Int Panis et al., 2010). Multiplying $V_{\mathrm{E}}$ by the average exposure concentration yields the average pollutant inhalation rate in mass per unit time.

Table 2 summarizes published traveling bicyclists' respiration parameters (see Supplemental Material for a description of the measurement methods). Minute ventilation has been reported as $22-59 \mathrm{~L} / \mathrm{min}$ for bicyclists: two to five times higher than for travelers in automobiles or at rest. Bernmark et al. (2006) found $V_{\mathrm{E}}$ peaks for bicycle messengers of up to $97 \mathrm{~L} / \mathrm{min}$. The ranges of minute ventilations in Table 2 are related to the different average travel speeds and heart rates among the studies (included in Table 2), as well as potentially other experimental differences such as terrain, bicycle weight and condition, weather, and subject fitness. Greater exertion increases $V_{\mathrm{E}}$ primarily by an increase in $V_{\mathrm{T}}$ at lower levels of exercise and by an increase in $f_{\mathrm{r}}$ at higher levels of exercise; $f_{\mathrm{r}}$ is the dominant factor at $70-80 \%$ of peak exercise level (Weisman, 2003). Trained professional bicyclists can achieve a greater increase in $V_{\mathrm{E}}$ through increases in $V_{\mathrm{T}}$ than recreational bicyclists (Faria, Parker, \& Faria, 2005b).

For active travelers such as bicyclists, $V_{\mathrm{E}}$ will be a function of travel characteristics that determine power requirements. The major determinants of power output during bicycling are energy losses (resistance) and changes in kinetic and potential energy (acceleration and grades, respectively). The largest energy losses are typically aerodynamic drag followed by rolling resistance. Rolling resistance becomes a more important factor at lower speeds and in still air, when drag is less severe (Di Prampero, Cortili, Mognoni, \& Saibene, 1979; Faria, Parker, \& Faria, 2005a; Martin, Milliken, Cobb, McFadden, \& Coggan, 1998; Olds, 2001; Whitt, 1971; Wilson, 2004). Nadeau, Truchon, Brochu, and Tardif 
Table 2. Respiration-related parameters measured for bicyclists

\begin{tabular}{|c|c|c|c|c|c|c|c|}
\hline Group & $\begin{array}{c}\text { Minute } \\
\text { ventilation, } V_{\mathrm{E}} \\
(\mathrm{L} / \mathrm{min})\end{array}$ & $\begin{array}{l}\text { Tidal } \\
\text { volume } \\
\text { (L) }\end{array}$ & $\begin{array}{l}\text { Breathing } \\
\text { frequency } \\
\left(\min ^{-1}\right)\end{array}$ & $\begin{array}{l}\text { Heart } \\
\text { rate } \\
(\mathrm{bpm})\end{array}$ & $\begin{array}{c}\text { Speed } \\
(\mathrm{kph})\end{array}$ & $\begin{array}{l}\text { Ratio of } \\
\text { bicycle/ } \\
\text { car, } V_{\mathrm{E}}{ }^{a}\end{array}$ & $\begin{array}{l}\text { Reference } \\
\text { and } \\
\text { method }^{\mathrm{b}}\end{array}$ \\
\hline \multirow[t]{2}{*}{ All } & 23.5 & & & 100 & 12 & 2.0 & 1 , estimated \\
\hline & 28.7 & & & & 13.5 & 2.5 & 2, on-road \\
\hline \multirow[t]{10}{*}{ Male } & 22 & & & 94 & 12 & 1.8 & 1 , estimated \\
\hline & 22.7 & & & & 14 & 1.9 & 3, on-road \\
\hline & 25 & 1.25 & 20 & & 8 & 2.1 & 4, lab \\
\hline & 28 & & & & & 2.3 & 5, lab \\
\hline & 31 & & & 107 & & 2.6 & 6 , estimated \\
\hline & 31.4 & & & & 19.5 & 2.6 & 3 , on-road \\
\hline & 44.2 & & & 138 & 20 & 3.7 & 7 , estimated \\
\hline & 50 & 1.92 & 26 & & 19 & 4.2 & 4, lab \\
\hline & 51.2 & & & & 24 & 4.3 & 3 , on-road \\
\hline & 59.1 & 2.2 & 27.9 & 129.6 & 20.5 & 4.9 & 8, on-road \\
\hline \multirow[t]{5}{*}{ Female } & 22.6 & & & & 14 & 2.1 & 3, on-road \\
\hline & 27.6 & & & 116 & 12 & 2.5 & 1 , estimated \\
\hline & 32.8 & & & & 19.5 & 3.0 & 3 , on-road \\
\hline & 46.2 & 1.4 & 32.7 & 140 & 19.5 & 4.2 & 8, on-road \\
\hline & 51.8 & & & & 24 & 4.7 & 3, on-road \\
\hline
\end{tabular}

Note: Blank cells are not reported. Methodologies are categorized as 'on-road' (direct on-road measurement of respiration using masks), 'lab' (laboratory ergometer-based respiration measurements), and 'estimated' (on-road measurement of heart rate and estimation of respiration using laboratory ergometer-based heart rate/ventilation relationships).

${ }^{a}$ Reference minute ventilation for car drivers of $12 \mathrm{~L} / \mathrm{min}$ for males, $11 \mathrm{~L} / \mathrm{min}$ for females, and $11.5 \mathrm{~L} /$ min for all, based on Adams (1993), Int Panis et al. (2010), O'Donoghue, Gill, McKevitt, and Broderick (2007), van Wijnen et al. (1995), Zuurbier, Hoek, Hazel, and Brunekreef (2009).

beferences: 1 (Zuurbier et al., 2009), 2 (van Wijnen et al., 1995), 3 (Adams, 1993), 4 (McNabola, Broderick, \& Gill, 2007), 5 (O’Donoghue et al., 2007), 6 (Bernmark, Wiktorin, Svartengren, Lewné, \& Åberg, 2006), 7 (Cole-Hunter et al., 2012), and 8 (Int Panis et al., 2010).

(2006) measured $V_{\mathrm{E}}$ of around 12, 23, and $35 \mathrm{~L} / \mathrm{min}$ for bicycle ergometer workloads of 0,50 , and $100 \mathrm{~W}$, respectively, suggesting that the subjects in the studies in Table 2 experienced workloads ranging from around $50 \mathrm{~W}$ to well over $100 \mathrm{~W}$ of power.

Compilations of physical activity data often use metabolic equivalent of task (MET) to compare energy expenditure with a standardized unit; a MET is defined as $\mathrm{MET}=\dot{e} / \mathrm{RMR}$, where $\dot{e}$ is the rate of metabolic energy production and RMR is the resting metabolic rate (Ainsworth et al., 2011a, 2011b; U.S. Environmental Protection Agency, 2009). RMR is an individual-specific value (varying across individuals), often assumed to be $3.5 \mathrm{ml}-\mathrm{O}_{2} / \mathrm{min}$ per $\mathrm{kg}$ body mass - i.e. $\mathrm{MET}=\dot{e} / K \cdot m$, where $K$ is a constant and $m$ is body mass. Thus, MET values are directly proportional to energy expenditure for an individual and inversely proportional to an individual's body mass for a given energy expenditure. ${ }^{3}$

Resting activities are at an MET of 1, while 'general' bicycling is at an MET of 7.5 and bicycling 'to/from work, self-selected pace' is at MET 6.8 in the 'Compendium of Physical Activities' (Ainsworth et al., 2011a, 2011b). The Compendium lists 16 different types of bicycling as activities with energy expenditures ranging from 3.5 MET for 'leisure' bicycling at $5.5 \mathrm{mph}$ to $16 \mathrm{MET}$ for competitive mountain bicycle racing. Non-sport bicycling has been estimated to require 3.5-9 
MET of energy expenditure, with power output of roughly 50-150 W, depending on the speed (Bernmark et al., 2006; De Geus, de Smet, Nijs, \& Meeusen, 2007; Whitt, 1971). MET values have been employed to estimate bicyclists' respiration for pollution dose assessments using both reference MET values and MET values estimated from accelerometer measurements; average accelerometerbased MET for bicycling was estimated at 6.58 with a corresponding ventilation rate of $41 \mathrm{~L} / \mathrm{min}$ (De Nazelle et al., 2012). Respiration was estimated from MET values using stochastic relationships between oxygen uptake rates and ventilation rates along with the individuals' body mass (De Nazelle, Rodríguez, \& CrawfordBrown, 2009; Johnson, 2002).

\subsection{Studies of Bicyclists' Pollution Intake}

Table 3 characterizes published studies of bicyclists' air pollution exposure, intake, uptake, or biomarkers that use spatially explicit exposure concentration data (modeled or measured). Studies are categorized according to how (and whether) they account for (1) respiration (i.e. intake), (2) uptake of gases or deposition of particles, and (3) health biomarkers. The last two dimensions are discussed in Sections 5 and 6, respectively. 'Constant' respiration refers to studies that apply fixed respiration rates by mode or individual; 'variable' respiration refers to studies that use varying respiration rates by trip or at a greater level of detail. The categorization in Table 3 proceeds roughly from least to most comprehensive $(\mathrm{A}-\mathrm{M})$ in terms of targeting farther along the exposure-health pathway, assessing linkages more directly (e.g. measuring versus assuming), and/or examining more intermediate steps between exposure and uptake or biomarkers.

Many studies consider only exposure concentrations and neglect the question of intake dose and the issue of varying respiration and energy expenditure by travel mode and condition (Type A). Similarly, some studies measure exposure concentrations and uptake doses or health biomarkers directly, but do not address the intermediate step of intake or respiration (Types J and K). Of the 19 studies in Table 3 that explicitly consider respiration, 16 use fixed values of $V_{\mathrm{E}}$ for each travel mode or individual (Types B-E, G, H, and L). Type B studies (7 of the 19) apply an assumed $V_{\mathrm{E}}$ for bicyclists based on other published research. Two studies (Types D and H) use bicycle ergometers in a laboratory to determine representative respiration values by mode. Of the eight studies that model respiration (Types C, F, G, L, and M), six use ergometers to develop individual subject functions to estimate on-road $V_{\mathrm{E}}$ from field-measured heart rate (HR), one uses previously developed $V_{\mathrm{E}}-\mathrm{HR}$ functions with field-measured HR, and one estimates respiration from accelerometerbased MET values - see Section 4.1. Only two of these eight studies (Types F and M) estimate intake using variable ventilation rates by trip (Cole-Hunter et al., 2012) or at 2 min aggregations (Nyhan, McNabola, \& Misstear, 2014).

Two studies in Table 3 directly measure on-road bicyclists' minute ventilation in order to estimate intake dose (Types E and I). Van Wijnen et al. (1995) use fixed mode-specific respiration rates that are the averages of measured on-road minute ventilation for a set of test subjects traveling on the same test routes as the concentration measurements, but at different times. Int Panis et al. (2010) use simultaneously monitored on-road respiration and concentration data to estimate intake dose. Combining tidal volume and pollutant concentration measurements, Int Panis et al. calculate breath-by-breath mass intake and sum over trips, thus including both respiration and duration effects on total intake. 
Table 3. Categorization of bicyclists' air pollution exposure, intake, uptake, and biomarker studies

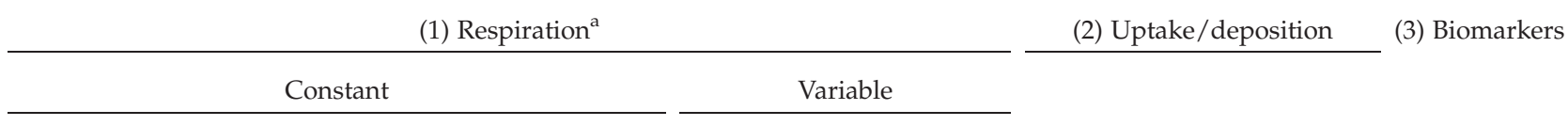

Study type Number of studies ${ }^{\mathrm{b}}$ Assumed Modeled Measured in-lab Measured on-road Modeled Measured on-road Assumed Modeled Measured Measured

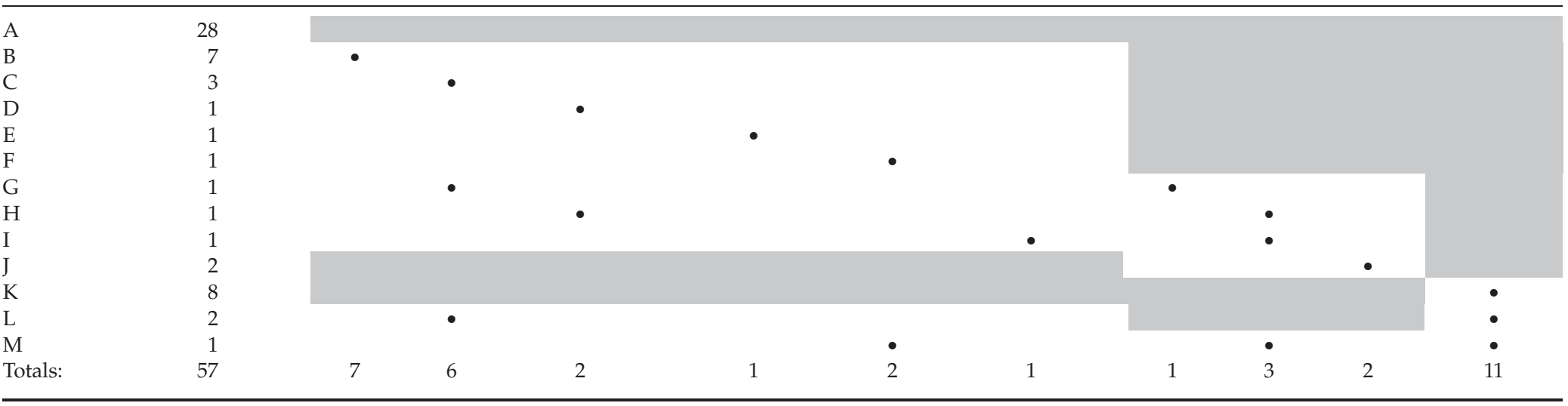

Note: Grey cells mean that dimension was not assessed (respiration, uptake, and biomarkers); $\bullet$ indicates the method of assessment for that dimension by each study type. A: Adams, Nieuwenhuijsen, and Colvile (2001), Adams, Nieuwenhuijsen, Colvile, McMullen, and Khandelwal (2001), Adams et al. (2002), Bean, Carslaw, Ashmore, Gillah, and Parkinson (2011), Berghmans et al. (2009), Bevan et al. (1991), Boogaard et al. (2009), Chan, Hung, and Qin (1994), Chertok et al. (2004), Dekoninck,

Botteldooren, and Int Panis (2013), Dons et al. (2013), Farrar, Dingle, and Tan (2001), Gee and Raper (1999), Hatzopoulou, Weichenthal, Barreau, et al. (2013), Hatzopoulou, Weichenthal, Dugum, et al. (2013), Hertel et al. (2008), Hong and Bae (2012), Kaur and Nieuwenhuijsen (2009), Kaur et al. (2005), Kendrick et al. (2011), Kingham et al. (2013, 1998), Kleiner and Spengler (1976), McNabola et al. (2009a), Ragettli et al. (2013), Sitzmann, Kendall, Watt, and Williams (1999), Strauss et al. (2012), Thai, McKendry, and Brauer (2008); B: Dirks, Sharma, Salmond, and Costello (2012), Dons et al. (2012), Fajardo and Rojas (2012), Huang et al. (2012), Quiros et al. (2013), Rank, Folke, and Homann Jespersen (2001), Yu et al. (2012); C: Bernmark et al. (2006), de Nazelle et al. (2012), Zuurbier et al. (2010); D: O’Donoghue et al. (2007); E: van Wijnen et al. (1995); F: Cole-Hunter et al. (2012); G: Vinzents et al. (2005); H: McNabola et al. (2008); I: Int Panis et al. (2010); J: Bergamaschi et al. (1999), Nwokoro et al. (2012); K: Bos et al. (2011), Cole-Hunter et al. (2013), Jacobs et al. (2010), Jarjour et al. (2013), Strak et al. (2010), Waldman et al. (1977), Weichenthal et al. (2011, 2012); L: Zuurbier, Hoek, Oldenwening, Meliefste, van den Hazel, et al. (2011), Zuurbier, Hoek, Oldenwening, Meliefste, Krop, et al. (2011); M: Nyhan, McNabola, and Misstear (2014).

${ }^{a}$ 'Constant' respiration means fixed respiration rates by mode or individual; 'variable' respiration means varying respiration by trip or greater level of detail.

b'Includes all published papers of on-road bicyclists' pollution exposure with spatially explicit exposure concentration data. 
Table 3 shows that there has been little assessment of the variability of bicyclists' respiration as they travel in an urban environment. If the variability in respiration is independent of exposure concentrations, then representative averages for each will suffice (assuming linearity). But there is likely to be spatial correlation between pollutant concentrations and bicyclist energy expenditure at locations such as intersections and hills, where both motor vehicles and bicyclists are required to generate more energy. There is also a potential correlation between exposure duration and exposure concentration at congested bottlenecks or busy intersections. At the route level, Cole-Hunter et al. (2013) found no significant differences in measured HR for routes with low and high proximity to traffic; they conclude that variability in UFP intake dose for bicyclists would be predominantly determined by exposure concentrations, not ventilation characteristics. But a wide range of bicyclists' respiration values have been reported (Section 4.1), and the lack of bicyclist intake dose studies considering variable respiration rates leaves the question open.

\subsection{Modal Comparisons of Pollution Intake}

Int Panis et al. (2010) argues that comparisons of exposure concentrations by travel mode (as in Section 3.1) are 'not entirely relevant' because of the dominating effect of breathing differences among modes. Modal comparisons of pollution intake dose go beyond exposure concentrations by including respiration to compare intake dose rates per unit time. More detailed comparisons also consider the intake effects of travel duration differences, assessing intake doses per trip or unit travel distance. For faster trips, the time spent in an alternative environment is typically neglected; this aspect may be important when the air quality at the trip destination is poor. Inherent speed differences by mode are problematic for modal comparisons of intake rates by either normalization.

Table 4 summarizes the 12 published modal comparisons that include respiration, showing the median and range for ratios of bicycle to alternative mode intake or uptake doses. Dose ratios are presented separately for the eight studies that compare doses per unit distance and the five studies that compare doses per unit time (one assesses both). For most pollutants, studies that compare doses per unit distance find greater bicycle/car dose ratios than comparisons per unit time, as expected from bicyclists' lower travel speeds. This body of literature is still much smaller than modal comparisons of exposure, but for the most part two to five times higher ventilation rates and slower travel speeds for bicyclists compared to motor vehicle passengers outweigh any beneficial exposure concentration differences. Bicyclists' doses are less consistent when compared to pedestrians, which is not surprising because walking is another active travel mode with elevated respiration. Pedestrians typically have lower respiration rates (McNabola et al., 2007) but also lower speeds, with counteracting effects on intake rates per unit distance.

Few of the modal comparisons of dose directly measure on-road respiration or model respiration as a function of travel characteristics beyond mode. This is important because travel attributes such as road grade and speed affect respiration and inhalation rates for bicyclists but not motorized modes. Intake doses per trip will be further affected by duration changes with route and destination choices, which are normally not varied in modal comparisons (as discussed in Section 3.1). Furthermore, active travelers tend to have unique demographics 
Table 4. Ratios of intake or uptake doses for bicyclists versus other modes

\begin{tabular}{|c|c|c|c|c|c|}
\hline & \multirow[b]{2}{*}{ Alternative mode } & \multicolumn{2}{|c|}{ Per unit distance $^{a}$} & \multicolumn{2}{|c|}{ Per unit time } \\
\hline & & $N^{\mathrm{b}}$ & Median (Range) & $N$ & Median (range) \\
\hline \multirow[t]{4}{*}{$\mathrm{CO}$} & Pedestrian & 1 & 0.80 & 0 & \\
\hline & Car/taxi & 3 & $1.09(0.36-4.67)$ & 1 & 0.87 \\
\hline & Bus & 3 & $1.63(1.07-4.67)$ & 0 & \\
\hline & Rail & 1 & 7.00 & 0 & \\
\hline \multirow[t]{3}{*}{$\mathrm{VOC}^{\mathrm{c}}$} & Pedestrian & 1 & 1.11 & 0 & \\
\hline & Car & 1 & 0.81 & 4 (2 studies) & $0.71(0.50-0.72)$ \\
\hline & Bus & 2 & $1.60(1.25-1.96)$ & 0 & \\
\hline $\mathrm{NO}_{2}$ & Car & 0 & & 1 & 3.08 \\
\hline \multirow[t]{3}{*}{ UFP } & Pedestrian & 2 & $0.68(0.51-0.84)$ & 0 & \\
\hline & Car & 3 & $5.42(1.00-10.42)$ & 1 & 2.09 \\
\hline & Bus & 1 & 1.90 & 1 & 1.87 \\
\hline \multirow[t]{4}{*}{$\mathrm{PM}_{2.5}$} & Pedestrian & 4 & $1.13(0.47-1.97)$ & 1 & 2.09 \\
\hline & Car/taxi & 5 & $3.36(1.38-10.88)$ & 1 & 1.70 \\
\hline & Bus & 4 & $1.77(1.06-4.78)$ & 2 & $3.14(1.91-4.36)$ \\
\hline & Rail & 1 & 2.56 & 1 & 2.29 \\
\hline \multirow[t]{4}{*}{$\mathrm{PM}_{10}$} & Pedestrian & 1 & 1.62 & 1 & 1.82 \\
\hline & Car & 1 & 6.75 & 1 & 1.66 \\
\hline & Bus & 1 & 3.21 & 2 & $2.13(1.15-3.10)$ \\
\hline & Rail & 1 & 3.06 & 1 & 2.21 \\
\hline \multirow[t]{3}{*}{$\mathrm{BC}$} & Pedestrian & 1 & 0.81 & 0 & \\
\hline & Car & 1 & 0.84 & 2 & $1.90(1.36-2.44)$ \\
\hline & Bus & 1 & 1.64 & 1 & 1.51 \\
\hline
\end{tabular}

Notes: Sources, per unit distance: CO: de Nazelle et al. (2012), Dirks et al. (2012), Huang et al. (2012); VOC: McNabola et al. (2008), O’Donoghue et al. (2007); UFP: Int Panis et al. (2010), de Nazelle et al. (2012), Quiros et al. (2013); PM 2.5: Huang et al. (2012), Int Panis et al. (2010), McNabola et al. (2008), de Nazelle et al. (2012), Nyhan et al. (2014), Quiros et al. (2013); PM 10 : Int Panis et al. (2010), Nyhan et al. (2014); BC: de Nazelle et al. (2012).

Sources, per unit time: CO: van Wijnen et al. (1995); VOC: Rank et al. (2001), van Wijnen et al. (1995); $\mathrm{NO}_{2}$ : van Wijnen et al. (1995); UFP: Zuurbier et al. (2010); $\mathrm{PM}_{2.5}$ : Nyhan et al. (2014), Zuurbier et al. (2010); PM $\mathrm{P}_{10}$ : Nyhan et al. (2014), Zuurbier et al. (2010); BC: Dons et al. (2012), Zuurbier et al. (2010). ${ }^{a}$ Values are ratios of bicycle to alternative mode doses in mass, particles, or ppb per unit distance (i.e. per $\mathrm{km}$ or per trip) or per unit time (i.e. per hour of travel); the table includes all studies that directly compare pollutant intake or uptake between travelers by bicycle and other modes for similar trips.

${ }^{\mathrm{b}} \mathrm{A}$ single mean value (weighted by number of samples) was computed for studies reporting separate results by routes or times of day. VOC doses per unit time are from two studies, with one reporting three different compounds.

${ }^{\mathrm{c}}$ Only reported values for BTEX compounds are included.

(Plaut, 2005), which could systematically impact respiration through physiological attributes such as sex and health condition (Adams, 1993).

\section{Bicyclists' Air Pollution Uptake}

A portion of inhaled pollutants are either absorbed (gases) or deposited (particles) onto the lining of the respiratory tract or into the bloodstream. Absorbed/deposited pollutants are then either expelled (through mucociliary clearance or desorption) or transported to body tissues. The air pollution uptake dose is the amount of pollutant that is not exhaled or expelled, but rather incorporated into the body (Figure 1). 
Table 5. Factors that increase pollutant uptake

\begin{tabular}{ll}
\hline Factor & \multicolumn{1}{c}{ Increased uptake with: } \\
\hline Exposure & \\
Concentration & Higher concentrations \\
Duration & Longer duration \\
Pollutant & Smaller particles \\
Particle size & More hydrophobic particles \\
Particle hygroscopicity & More blood- and lipid-soluble compounds \\
Gas solubility & \\
Respiration/physiology & Greater ventilation \\
Breath volume flow rate $\left(V_{\mathrm{E}}\right)$ & Greater tidal volume \\
Depth of breathing $\left(V_{\mathrm{T}}\right)$ & Oral breathing \\
Path of breathing & Greater perfusion \\
Cardiac output (lung perfusion) & Higher metabolic rate \\
Metabolic rate & \\
\hline
\end{tabular}

Table 5 summarizes the factors that are expected to increase pollutant uptake for bicyclists. The first two factors reflect the exposure in terms of concentration and duration. The next set of factors in Table 5 is attributes of the pollutants that determine uptake dose (independent of travel characteristics). Particle size is important for PM uptake because deposition and clearance rates vary with particle size. UFP deposition is also influenced by the particles' growth characteristics in high humidity conditions such as in lung airways (hygroscopicity). Gas reactivity and solubility in blood and lipids are similarly important because they affect absorption and diffusion rates (Daigle et al., 2003; International Commission on Radiological Protection [ICRP] Task Group, 1994; Löndahl et al., 2007; McNabola et al., 2008; Ott et al., 2007; West, 2012).

Table 5 also summarizes the physiology and respiration factors that influence uptake. Intake dose is determined by $V_{\mathrm{E}}$ and the exposure concentration; uptake dose is further influenced by the depth of respiration $\left(V_{\mathrm{T}}\right)$ and the amount of oral breathing. Greater uptake fractions of inhaled PM occur during deeper and more oral breathing (ICRP Task Group, 1994), which are associated with higher levels of exertion (Samet, Lambert, James, Mermier, \& Chick, 1993; Weisman, 2003). Daigle et al. (2003) found that when subjects' $V_{\mathrm{E}}$ increased from 11.5 to $38.1 \mathrm{~L} / \mathrm{min}$ the deposition fraction $(\mathrm{DF})$, the portion of particles that are not exhaled after inhalation, increased from 0.66 to 0.83 by number of particles and from 0.58 to 0.76 by mass of particles. Thus, a $V_{\mathrm{E}}$ increase by a factor of 3.3 led to a total deposition increase by a factor of 4.5 due to a higher DF. Löndahl et al. (2007) found only small changes in DF for UFP (by less than 0.03) during exercise when compared to rest ( $V_{\mathrm{E}}$ of 33.9 versus $7.8 \mathrm{~L} / \mathrm{min}$ ), but both of these studies found that established models under-predicted deposition of UFP especially during exercise.

Uptake rates for gaseous pollutants are also affected by the characteristics of the gas and the level of physical exertion. VOC and CO uptake rates are several times greater during exercise than at rest for a given exposure concentration. But the uptake fraction of inhaled gases tends to decrease with exertion level because gas uptake rates increase more slowly than intake rates with exercise (Astrand, 1985; Astrand, Engstrom, \& Ovrum, 1978; Filley, MacIntosh, \& Wright, 1954; Nadeau et al., 2006; Pezzagno, Imbriani, Ghittori, \& Capodaglio, 1988). Diffu- 
sion-limited gases such as $\mathrm{CO}$ are primarily impacted by the diffusing capacity of the lungs, which can increase by a factor of 3 during exercise (West, 2012). Uptake rates for perfusion-limited gases such as low-solubility VOC and $\mathrm{NO}_{2}$ increase with ventilation and perfusion of the lungs, gas partial pressure differences between blood and air, and gas solubility in blood (Astrand, 1985; Csanády \& Filser, 2001; Farhi, 1967; West, 2012). As blood concentrations approach equilibrium with inspired air, the uptake rate will fall to the steady-state rate of metabolic clearance (Csanády \& Filser, 2001; Wallace, Pellizzari, \& Gordon, 1993). Although exercise increases ventilation and perfusion, it also can decrease the rate at which pollutants are metabolized by reducing blood flow to the liver reducing the steady-state uptake rate while simultaneously increasing blood concentrations (Astrand, 1985; Csanády \& Filser, 2001; Kumagai \& Matsunaga, 2000; Nadeau et al., 2006).

Detailed uptake models allow estimation of different locations/tissues of pollutant uptake, which is relevant because of varying susceptibility to negative health effects from air pollution uptake by different tissues. Common uptake models include body compartment and physiologically based pharmacokinetic models for gases and human respiratory tract models for both gases and PM (HeinrichRamm et al., 2000; Hofmann, 2011; ICRP Task Group, 1994; King et al., 2011; Ott et al., 2007; Wallace et al., 1993; Wallace, Nelson, Pellizzari, \& Raymer, 1997). Uptake models are generally validated using much steadier air concentrations than have been observed in on-road environments, so it is not clear how applicable they are for on-road uptake analysis with highly transient exposure concentrations.

Uptake of air pollutants by bicyclists has been studied less than exposure concentrations or intake doses (6 of the 57 studies in Table 3 explicitly consider uptake). Vinzents et al. (2005) conservatively estimate deposition as linearly proportional to workload (on average 43\% higher deposition of PM while bicycling than at rest). Int Panis et al. (2010) use DF that vary with $V_{\mathrm{E}}, V_{\mathrm{T}}$, and particle size, based on two previous studies of particle deposition (Chalupa, Morrow, Oberdorster, Utell, \& Frampton, 2004; Daigle et al., 2003). Although other factors in Table 5 were not explicitly modeled, these reference studies used physically active subjects and traffic exhaust particles. Intake doses of UFP were 4.2-6.6 times higher for bicyclists than car passengers, while uptake doses were 5.1-8.3 times higher - despite lower or roughly equivalent exposure concentrations for bicyclists. $\mathrm{PM}_{2.5}$ comparisons were similar, with intake doses 5.77.6 times higher for bicyclists than car passengers, but uptake doses 8.0-12.0 times higher.

McNabola et al. (2008) modeled uptake of VOC and $\mathrm{PM}_{2.5}$ using the International Commission on Radiological Protection (ICRP) human respiratory tract model (ICRP Task Group, 1994) with on-road measured exposure concentrations and laboratory-measured respiration characteristics for bicycle, pedestrian, car, and bus modes. The ICRP model can include all relevant factors in Table 5 except lung perfusion, though the assumed fraction of oral breathing is not reported by McNabola et al. (2008). Bicyclists had the highest total lung deposition of $\mathrm{PM}_{2.5}$ and the second highest absorption of VOC over similar trips to other modes. Breathing characteristics (frequency, tidal volume) and VOC solubility affected the uptake dose and the location of absorption, with more benzene absorbed deep in the lungs for bicyclists and pedestrians. Breathing differences also affected benzene absorption more than 1,3-butadiene absorption because of 
benzene's lower solubility. McNabola et al. (2007) similarly model VOC uptake by bicyclists using different travel speeds, but with assumed (rather than measured) exposure concentrations. They found that higher bicycling speeds reduce VOC absorption over a fixed travel distance because the increase in respiration rate is smaller than the reduction in exposure duration.

The same ICRP model was also applied by Nyhan et al. (2014) to estimate $\mathrm{PM}_{2.5}$ and $\mathrm{PM}_{10}$ lung deposition for trips by bicycle, foot, bus, and train. Their estimates indicate that bicyclists' PM intake and uptake per trip is disproportionately higher than exposure concentrations compared to other modes. But the cross-mode ratios are equivalent for modeled intake and deposition, suggesting that only ventilation rate $V_{\mathrm{E}}$ was varied by mode in the uptake model.

Bicyclists' uptake of traffic-related VOC was directly measured by sampling blood and urine concentrations of BTEX compounds (benzene, toluene, ethylbenzene, and xylenes) by Bergamaschi et al. (1999). They found significant increases of benzene and toluene in blood for bicyclists in urban areas, and significant increases of toluene and xylenes in urine. Although uptake was directly measured, respiration was not measured, and there was no discussion of pollutant intake or inhalation, which inhibits placement of their findings in the larger context of the emissions-health pathway (Figure 1). Nwokoro et al. (2012) directly measured uptake doses of BC by bicyclists and non-bicyclists (pedestrians and public transit riders) in London by sampling airway macrophages. They found significantly higher $(63 \%)$ doses of BC for bicyclists, correlated with higher commute exposure concentrations. Bicyclists also had almost twice as long commute durations, and experienced $41 \%$ of daily BC exposure during the commute (when compared with 19\% for non-bicyclists).

The few studies of bicyclists' pollution uptake suggest that PM uptake doses are disproportionally greater for bicyclists than intake doses or exposure concentrations when compared with other modes. Bicyclists' uptake doses of gaseous pollutants are also disproportionately higher than exposure concentrations when compared with other modes, but have yet to be directly compared with intake doses. Uptake dose is the closest measure of health risks for exposed travelers, but connections to health outcomes still require application of a dose-response function that reflects the toxicity of the pollutants, the susceptibility of the travelers, and other factors (Cho et al., 2009; ICRP Task Group, 1994).

\section{Health Effects of Bicyclists' Air Pollution Uptake}

Linkages between long-term exposure to traffic-related air pollution and health impacts have been established, as described elsewhere (Bell, 2012; Brook et al., 2010; Brugge, Durant, \& Rioux, 2007; Health Effects Institute, 2010; Nawrot et al., 2011; Pope \& Dockery, 2006; Samet, 2007). Long-term health effects studies show elevated risk for development of asthma, reduced lung function, increased blood pressure, and cardiac and pulmonary mortality. An important gap for traveler health studies, though, is a lack of data on the health effects of chronic high-intensity but short-duration doses (Zuurbier, Hoek, Oldenwening, Meliefste, Krop, et al., 2011). Some evidence exists of effects on mortality and cardiovascular/pulmonary hospital admissions for short-term exposure to traffic-related air pollution in general, and particularly PM and UFP (Knibbs et al., 2011; McCreanor et al., 2007; Michaels \& Kleinman, 2000; Peters et al., 
2004). A recent study indicates increased risk of acute myocardial infarction onset after travel specifically for bicyclists - though the risk is not higher than for other modes (Peters et al., 2013).

Health effects studies of bicyclists' exposure to air pollution have focused on respiratory and cardiovascular biomarkers following acute (0.5-2 h) exposures to traffic (11 studies of Types $\mathrm{K}-\mathrm{M}$ in Table 3). Biomarkers are physiological indicators in the pathway of the morbidity and mortality outcomes studied in epidemiology; for example, blood cell counts can be indicators of systemic inflammation, and systemic inflammation is linked to cardiovascular disease (Brook et al., 2010). Unfortunately, even when acute health effects are recognized in the form of biomarkers, the broader health significance is often not known especially in the context of chronic daily exposures.

Studies of bicyclists' biomarkers show inconsistent results, with 4 of 11 reporting insignificant acute effects and others reporting some cardiovascular or respiratory biomarker changes. No significant changes in bicyclists' respiratory or cardiovascular biomarkers were reported in four studies of acute on-road exposure (Jarjour et al., 2013; Waldman et al., 1977; Zuurbier, Hoek, Oldenwening, Meliefste, van den Hazel, et al., 2011; Zuurbier, Hoek, Oldenwening, Meliefste, Krop, et al., 2011). Jacobs et al. (2010) found a significant but small increase in a single indicator of blood inflammation for bicyclists, with 'unclear' health implications. Cole-Hunter et al. (2013) found significant differences in nasal and throat irritation between bicyclists in high-exposure and low-exposure routes, but no significant differences for airway inflammation biomarkers. Strak et al. (2010) found mostly insignificant changes in respiratory function biomarkers for bicyclists, though UFP and soot exposure were weakly associated with a biomarker of airway inflammation (exhaled NO) and degraded lung function. Weichenthal et al. (2011) found significant associations between UFP, ozone $\left(\mathrm{O}_{3}\right)$, and $\mathrm{NO}_{2}$ exposures during travel and cardiovascular risk indicators (changes in heart rate variability), but no strong associations between intraffic exposure and respiratory biomarkers. Further analysis of individual VOC in the data set found 'evidence of possible associations ... for a small number of compounds' with biomarkers of lung inflammation, lung function, and heart rate variability (Weichenthal et al., 2012). Nyhan et al. (2014) found significant associations between decreased heart rate variability and $\mathrm{PM}_{2.5}$ and $\mathrm{PM}_{10}$ doses - stronger for bicyclists and pedestrians than other modes. Bos et al. (2011) took a different approach and found that PM exposure during bicycling can suppress a positive exercise-induced health biomarker associated with cognitive performance. Though again, the effects of chronic exposure are still unknown.

This review does not address the health impacts of bicycling-related crashes and physical activity, only air pollution uptake. However, a review of five recent health impact assessments for bicycling concludes that the physical activity benefits of bicycling far outweigh the crash safety and air pollution risks - by factors of 9-96 (Teschke, Reynolds, Ries, Gouge, \& Winters, 2012). The air pollution risks in these assessments are based on extrapolations of epidemiological evidence for long-term health outcomes, and limited by the continued uncertainty of health effects of chronic daily uptake of air pollution by physically active travelers. 


\section{Summary}

This is the first review to specifically address bicyclists' health risks from trafficrelated air pollution and to explicitly include intake and uptake doses in addition to exposure concentrations. Bicyclists' pollution exposure concentrations are highly variable, with median increases of up to $102 \%$ (for gaseous hydrocarbons) on high-traffic versus low-traffic routes. Bicyclists' relative exposure concentrations compared to other modes are inconsistent, varying by pollutant, facility, route, and city. Bicyclists' exposure concentrations are most affected by wind and proximity to motor vehicle traffic, though few studies have incorporated detailed, concurrent traffic data.

Bicyclists' pollution intake doses tend to be higher than motorized modes due to their two to five times higher respiration rates. Bicyclists' respiration and intake dose increase with bicycle travel speed and exertion, but only 12 of the 57 studies with spatially explicit bicyclist exposure concentration data include any measurement of respiration. Furthermore, only three of those studies consider variable bicyclist respiration rates, and there has been almost no assessment of the variability in respiration with trip characteristics (including correlation with exposure concentrations).

Bicyclists' pollution uptake doses are affected by the intake dose, pollutant characteristics, breathing depth and pathway, and other individual and physiological factors. Uptake rates tend to increase with exertion level, affecting bicyclists more than motorized travelers. There are clear links between trafficrelated air pollution exposure and negative health outcomes in urban populations. However, the health effects of chronic daily air pollution uptake by bicyclists are still unknown. More research is needed on health impacts of pollution exposure because some studies of bicyclists' biomarkers show significant acute respiratory effects while other studies show insignificant effects.

To reduce exposure concentrations, spatial and temporal separation of bicyclists from motor vehicle traffic can be achieved with separated bicycle facilities, lowvolume routes, and off-peak travel. These are potential 'win-win' strategies because bicyclists already prefer low-traffic routes and bicycle-specific facilities (Broach et al., 2012; Dill, 2009; Kang \& Fricker, 2013; Wardman, Tight, \& Page, 2007) and separated bicycle facilities could also improve safety (Lusk et al., 2011; Reynolds, Harris, Teschke, Cripton, \& Winters, 2009; Teschke, Harris, et al., 2012). Regarding intake doses, other likely mitigation strategies would be to prioritize separation from traffic in locations where bicyclists' respiration is expected to be high (steep grades, for example) or to reduce energy expenditure requirements (by reducing required stops, for example) in locations where pollutant concentrations are known to be high.

\section{Research Gaps and Opportunities}

This literature review reveals steady progress toward a better understanding of air pollution uptake by bicyclists. However, several significant research gaps deserve attention. Although the literature suggests that traffic-related air pollution uptake is higher for bicyclists than for travelers using motorized modes, persistent uncertainty in the intensity and effects of pollution uptake means that transportation planners and decision-makers are unable to consider bicyclists' air pollution risks in a precise way. More research is needed to provide better quantification 
and understanding of the relative health benefits of alternative bicycle facility designs, bicycle network designs, and route options. Some research topics that can bring us closer to achieving these goals include

- study of the on-road variability of respiration and air quality for traveling bicyclists, including a broader array of pollutants (e.g. ground-level ozone);

- the impact of bicycle trip attributes such as road grade, road surface, travel speed, and number of stops on respiration rates for bicyclists;

- the impacts of bicycle facility design features on exposure concentrations (distance from motor vehicle travel lanes, physical barriers, intersection treatments such as 'bike boxes', etc.);

- the impacts of traffic flow characteristics on bicyclists' exposure concentrations, including traffic speeds, volumes, and queuing along arterials or at major intersections;

- inter-modal pollution exposure comparisons that apply more comprehensive and representative modal travel characteristics (trip location and distance, traveler demographics, route preferences) and that consider variable respiration (especially for active travelers);

- characterization of different bicyclist types (e.g. commuters and recreational riders) and demographic factors that can impact respiration or health effects; these factors include physiology (height, weight, and respiratory health), riding style (speed, acceleration, and response to grades), and equipment (weight, condition, and baggage);

- analysis of bicyclists' pollutant doses along different types of routes and facilities, to enable health impact assessments; and

- development of dose-response functions for health effects of chronic shortduration high-intensity air pollution exposure episodes.

\section{Acknowledgements}

The authors thank the anonymous reviewers for their thorough comments and helpful suggestions for the paper. Alexander Bigazzi is supported by a Graduate Research Fellowship from the U.S. National Science Foundation (Grant No. DGE1057604).

\section{Notes}

1. Traffic data are reported in a companion paper, Kaur and Nieuwenhuijsen (2009).

2. Traffic data are only used in a companion paper, McNabola et al. (2009b).

3. It should be noted that metabolic energy expenditure during bicycling is the sum of energy expenditure for baseline functions and the rate of external work (Olds, 2001). Assuming that the baseline energy expenditure is roughly equal to the RMR, the MET can be expressed as a function of external power output $p$ as MET $=(1+p /$ RMR). Thus, MET values increase linearly (but not proportionally) with the external power demands of bicycling.

\section{References}

Adams, H. S., Nieuwenhuijsen, M. J., \& Colvile, R. N. (2001). Determinants of fine particle (PM2. 5) personal exposure levels in transport microenvironments, London, UK. Atmospheric Environment, 35(27), $4557-4566$. 
Adams, H. S., Nieuwenhuijsen, M. J., Colvile, R. N., McMullen, M. A. S., \& Khandelwal, P. (2001). Fine particle (PM2. 5) personal exposure levels in transport microenvironments, London, UK. Science of the Total Environment, 279(1-3), 29-44.

Adams, H. S., Nieuwenhuijsen, M. J., Colvile, R. N., Older, M. J., \& Kendall, M. (2002). Assessment of road users' elemental carbon personal exposure levels, London, UK. Atmospheric Environment, 36(34), 5335-5342.

Adams, W. C. (1993). Measurement of breathing rate and volume in routinely performed daily activities. U.S. Environmental Protection Agency. Retrieved from http://hero.epa.gov/index.cfm?action=reference. details\&reference_id $=77086$

Ainsworth, B. E., Haskell, W. L., Herrmann, S. D., Meckes, N., Bassett, D. R., Tudor-Locke, C., ... Leon, A. S. (2011a). 2011 compendium of physical activities: A second update of codes and MET values. Medicine and Science in Sports and Exercise, 43(8), 1575-1581.

Ainsworth, B. E., Haskell, W. L., Herrmann, S. D., Meckes, N., Bassett, D. R., Tudor-Locke, C., ... Leon, A. S. (2011b). The Compendium of Physical Activities Tracking Guide. Healthy Lifestyles Research Center, College of Nursing \& Health Innovation, Arizona State University. Retrieved June 11, 2013, from https://sites.google.com/site/compendiumofphysicalactivities/home

Astrand, I. (1985). Uptake of solvents from the lungs. British Journal of Industrial Medicine, 42(4), 217218. doi:10.1136/oem.42.4.217

Astrand, I., Engstrom, J., \& Ovrum, P. (1978). Exposure to xylene and ethylbenzene: I. Uptake, distribution and elimination in man. Scandinavian Journal of Work and Environmental Health, 4, 185-194.

Badland, H. M., \& Duncan, M. J. (2009). Perceptions of air pollution during the work-related commute by adults in Queensland, Australia. Atmospheric Environment, 43(36), 5791-5795. doi:10.1016/j. atmosenv.2009.07.050

Bean, T., Carslaw, N., Ashmore, M., Gillah, A., \& Parkinson, C. (2011). How does exposure to nitrogen dioxide compare between on-road and off-road cycle routes? Journal of Environmental Monitoring, 13(4), 1039. doi:10.1039/c0em00332h

Bell, M. (2012). Assessment of the health impacts of particulate matter characteristics (Research Report, 161, pp. 5-38). Boston, MA: Health Effects Institute.

Bergamaschi, E., Brustolin, A., De Palma, G., Manini, P., Mozzoni, P., Andreoli, R., ... Mutti, A. (1999). Biomarkers of dose and susceptibility in cyclists exposed to monoaromatic hydrocarbons. Toxicology Letters, 108(2-3), 241-247. doi:10.1016/S0378-4274(99)00095-8

Berghmans, P., Bleux, N., Int Panis, L., Mishra, V. K., Torfs, R., \& Van Poppel, M. (2009). Exposure assessment of a cyclist to PM10 and ultrafine particles. Science of the Total Environment, 407(4), 1286-1298. doi:10.1016/j.scitotenv.2008.10.041

Bernmark, E., Wiktorin, C., Svartengren, M., Lewné, M., \& Åberg, S. (2006). Bicycle messengers: Energy expenditure and exposure to air pollution. Ergonomics, 49(14), 1486-1495. doi:10.1080/ 00140130600708206

Bevan, M. A. J., Proctor, C. J., Baker-Rogers, J., \& Warren, N. D. (1991). Exposure to carbon monoxide, respirable suspended particulates and volatile organic compounds while commuting by bicycle. Environmental Science \& Technology, 25(4), 788-791. doi:10.1021/es00016a026

Boogaard, H., Borgman, F., Kamminga, J., \& Hoek, G. (2009). Exposure to ultrafine and fine particles and noise during cycling and driving in 11 Dutch cities. Atmospheric Environment, 43(27), 42344242. doi:10.1016/j.atmosenv.2009.05.035

Bos, I., Jacobs, L., Nawrot, T. S., de Geus, B., Torfs, R., Int Panis, L., ... Meeusen, R. (2011). No exerciseinduced increase in serum BDNF after cycling near a major traffic road. Neuroscience Letters, 500(2), 129-132. doi:10.1016/j.neulet.2011.06.019

Broach, J., Dill, J., \& Gliebe, J. (2012). Where do cyclists ride? A route choice model developed with revealed preference GPS data. Transportation Research Part A: Policy and Practice, 46(10), 1730-1740. doi:10.1016/j.tra.2012.07.005

Brook, R. D., Rajagopalan, S., Pope, C. A., Brook, J. R., Bhatnagar, A., Diez-Roux, A. V., ... Kaufman, J. D. (2010). Particulate matter air pollution and cardiovascular disease an update to the scientific statement from the American Heart Association. Circulation, 121(21), 2331-2378. doi:10.1161/CIR. 0b013e3181dbece1

Brugge, D., Durant, J., \& Rioux, C. (2007). Near-highway pollutants in motor vehicle exhaust: A review of epidemiologic evidence of cardiac and pulmonary health risks. Environmental Health, 6(1), 23-34.

Chalupa, D. C., Morrow, P. E., Oberdorster, G., Utell, M. J., \& Frampton, M. W. (2004). Ultrafine particle deposition in subjects with asthma. Environmental Health Perspectives, 112(8), 879-882. 
Chan, L. Y., Hung, W. T., \& Qin, Y. (1994). Vehicular emission exposure of bicycle commuters in the urban area of Guangzhou, South China (PRC). Environment International, 20(2), 169-177. doi:10. 1016/0160-4120(94)90134-1

Chertok, M., Voukelatos, A., Sheppeard, V., \& Rissel, C. (2004). Comparison of air pollution exposure for five commuting modes in Sydney — car, train, bus, bicycle and walking. Health Promotion Journal of Australia, 15(1), 63-67.

Cho, S.-H., Tong, H., McGee, J. K., Baldauf, R. W., Krantz, Q. T., \& Gilmour, M. I. (2009). Comparative toxicity of size-fractionated airborne particulate matter collected at different distances from an urban highway. Environmental Health Perspectives, 117(11), 1682-1689. doi:10.1289/ehp.0900730

Clifford, M. J., Clarke, R., \& Riffat, S. B. (1997). Local aspects of vehicular pollution. Atmospheric Environment, 31(2), 271-276. doi:10.1016/1352-2310(96)00205-1

Cole-Hunter, T., Morawska, L., Stewart, I., Hadaway, M., Jayaratne, R., \& Solomon, C. (2013). Utility of an alternative bicycle commute route of lower proximity to motorised traffic in decreasing exposure to ultra-fine particles, respiratory symptoms and airway inflammation - a structured exposure experiment. Environmental Health, 12(1). doi:10.1186/1476-069X-12-29

Cole-Hunter, T., Morawska, L., Stewart, I., Jayaratne, R., \& Solomon, C. (2012). Inhaled particle counts on bicycle commute routes of low and high proximity to motorised traffic. Atmospheric Environment, 61. doi:10.1016/j.atmosenv.2012.06.041

Csanády, G. A., \& Filser, J. G. (2001). The relevance of physical activity for the kinetics of inhaled gaseous substances. Archives of Toxicology, 74(11), 663-672. doi:10.1007/s002040000158

Daigle, C. C., Chalupa, D. C., Gibb, F. R., Morrow, P. E., Oberdörster, G., Utell, M. J., \& Frampton, M. W. (2003). Ultrafine particle deposition in humans during rest and exercise. Inhalation Toxicology, 15(6), 539-552. doi:10.1080/08958370304468

De Geus, B., de Smet, S., Nijs, J., \& Meeusen, R. (2007). Determining the intensity and energy expenditure during commuter cycling. British Journal of Sports Medicine, 41(1), 8-12. doi:10.1136/bjsm.2006. 027615

De Hartog, J. J., Boogaard, H., Nijland, H., \& Hoek, G. (2010). Do the health benefits of cycling outweigh the risks? Environmental Health Perspectives, 118(8), 1109-1116. doi:10.1289/ehp.0901747

Dekoninck, L., Botteldooren, D., \& Int Panis, L. (2013). An instantaneous spatiotemporal model to predict a bicyclist's black carbon exposure based on mobile noise measurements. Atmospheric Environment, 79, 623-631. doi:10.1016/j.atmosenv.2013.06.054

De Nazelle, A., Fruin, S., Westerdahl, D., Martinez, D., Ripoll, A., Kubesch, N., \& Nieuwenhuijsen, M. (2012). A travel mode comparison of commuters' exposures to air pollutants in Barcelona. Atmospheric Environment, 59(0), 151-159. doi:10.1016/j.atmosenv.2012.05.013

De Nazelle, A., Rodríguez, D. A., \& Crawford-Brown, D. (2009). The built environment and health: Impacts of pedestrian-friendly designs on air pollution exposure. Science of the Total Environment, 407(8), 2525-2535. doi:10.1016/j.scitotenv.2009.01.006

Dill, J. (2009). Bicycling for transportation and health: The role of infrastructure. Journal of Public Health Policy, 30, S95-S110. doi:10.1057/jphp.2008.56

Di Prampero, P. E., Cortili, G., Mognoni, P., \& Saibene, F. (1979). Equation of motion of a cyclist. Journal of Applied Physiology, 47(1), 201-206.

Dirks, K. N., Sharma, P., Salmond, J. A., \& Costello, S. B. (2012). Personal exposure to air pollution for various modes of transport in Auckland, New Zealand. Open Atmospheric Science Journal, 6(1), 84-92.

Dons, E., Int Panis, L., Van Poppel, M., Theunis, J., \& Wets, G. (2012). Personal exposure to black carbon in transport microenvironments. Atmospheric Environment, 55, 392-398. doi:10.1016/j.atmosenv.2012. 03.020

Dons, E., Temmerman, P., Van Poppel, M., Bellemans, T., Wets, G., \& Int Panis, L. (2013). Street characteristics and traffic factors determining road users' exposure to black carbon. Science of the Total Environment, 447, 72-79. doi:10.1016/j.scitotenv.2012.12.076

El-Fadel, M., \& Abi-Esber, L. (2009). In-vehicle exposure to carbon monoxide emissions from vehicular exhaust: A critical review. Critical Reviews in Environmental Science and Technology, 39(8), 585-621. doi:10.1080/10643380701798264

Fajardo, O. A., \& Rojas, N. Y. (2012). Particulate matter exposure of bicycle path users in a high-altitude city. Atmospheric Environment, 46(0), 675-679. doi:10.1016/j.atmosenv.2011.09.047

Farhi, L. E. (1967). Elimination of inert gas by the lung. Respiration Physiology, 3(1), 1-11. doi:10.1016/ 0034-5687(67)90018-7

Faria, E. W., Parker, D. L., \& Faria, I. E. (2005a). The science of cycling: Factors affecting performance part 2. Sports Medicine, 35(4), 313-337. 
Faria, E. W., Parker, D. L., \& Faria, I. E. (2005b). The science of cycling: Physiology and training — part 1. Sports Medicine, 35(4), 285-312.

Farrar, D., Dingle, P., \& Tan, R. (2001). Exposure to nitrogen dioxide in buses, taxis, and bicycles in Perth, Western Australia. Bulletin of Environmental Contamination and Toxicology, 66(4), 433-438. doi:10.1007/s001280024

Filley, G. F., MacIntosh, D. J., \& Wright, G. W. (1954). Carbon monoxide uptake and pulmonary diffusing capacity in subjects at rest and during exercise. Journal of Clinical Investigation, 33(4), 530-539.

Forastiere, F., \& Agabiti, N. (2013). Assessing the link between air pollution and heart failure. The Lancet. doi:10.1016/S0140-6736(13)61167-8

Gee, I. L., \& Raper, D. W. (1999). Commuter exposure to respirable particles inside buses and by bicycle. Science of the Total Environment, 235(1-3), 403-405. doi:10.1016/S0048-9697(99)00247-8

Gordon, M., Staebler, R. M., Liggio, J., Li, S.-M., Wentzell, J., Lu, G., . . Brook, J. R. (2012). Measured and modeled variation in pollutant concentration near roadways. Atmospheric Environment, 57(0), 138145. doi:10.1016/j.atmosenv.2012.04.022

Gulliver, J., \& Briggs, D. J. (2004). Personal exposure to particulate air pollution in transport microenvironments. Atmospheric Environment, 38(1), 1-8.

Hatzopoulou, M., Weichenthal, S., Barreau, G., Goldberg, M., Farrell, W., Crouse, D., \& Ross, N. (2013). A web-based route planning tool to reduce cyclists' exposures to traffic pollution: A case study in Montreal, Canada. Environmental Research, 123, 58-61. doi:10.1016/j.envres.2013.03.004

Hatzopoulou, M., Weichenthal, S., Dugum, H., Pickett, G., Miranda-Moreno, L., Kulka, R., ... Goldberg, M. (2013). The impact of traffic volume, composition, and road geometry on personal air pollution exposures among cyclists in Montreal, Canada. Journal of Exposure Science and Environmental Epidemiology. doi:10.1038/jes.2012.85

Health Effects Institute. (2010). Traffic-related air pollution: A critical review of the literature on emissions, exposure, and health effects (Special Report 17). Boston, MA: Health Effects Institute.

Heinrich-Ramm, R., Jakubowski, M., Heinzow, B., Christensen, J. M., Olsen, E., \& Hertel, O. (2000). Biological monitoring for exposure to volatile organic compounds (VOCs) (IUPAC Recommendations 2000). Pure and Applied Chemistry, 72(3), 385-436. doi:10.1351/pac200072030385

Hertel, O., Hvidberg, M., Ketzel, M., Storm, L., \& Stausgaard, L. (2008). A proper choice of route significantly reduces air pollution exposure - a study on bicycle and bus trips in urban streets. Science of the Total Environment, 389(1), 58-70. doi:10.1016/j.scitotenv.2007.08.058

Hofmann, W. (2011). Modelling inhaled particle deposition in the human lung - a review. Journal of Aerosol Science, 42(10), 693-724. doi:10.1016/j.jaerosci.2011.05.007

Hong, E.-S., \& Bae, C.-H. (2012). Exposure of bicyclists to air pollution in Seattle, Washington hybrid. Transportation Research Record: Journal of the Transportation Research Board, 2270, 59-66. doi:10.3141/ 2270-08

Huang, J., Deng, F., Wu, S., \& Guo, X. (2012). Comparisons of personal exposure to PM2.5 and CO by different commuting modes in Beijing, China. Science of the Total Environment, 425, 52-59. doi:10. 1016/j.scitotenv.2012.03.007

International Commission on Radiological Protection Task Group. (1994). Human respiratory tract model for radiological protection. Annals of the ICRP, 24(1-3), 1-480.

Int Panis, L., de Geus, B., Vandenbulcke, G., Willems, H., Degraeuwe, B., Bleux, N., ... Meeusen, R. (2010). Exposure to particulate matter in traffic: A comparison of cyclists and car passengers. Atmospheric Environment, 44(19), 2263-2270. doi:10.1016/j.atmosenv.2010.04.028

Jacobs, L., Nawrot, T., de Geus, B., Meeusen, R., Degraeuwe, B., Bernard, A., . . Int Panis, L. (2010). Subclinical responses in healthy cyclists briefly exposed to traffic-related air pollution: An intervention study. Environmental Health, 9(1), 64. doi:10.1186/1476-069X-9-64

Jarjour, S., Jerrett, M., Westerdahl, D., Nazelle, A. de Hanning, C., Daly, L., . . Balmes, J. (2013). Cyclist route choice, traffic-related air pollution, and lung function: A scripted exposure study. Environmental Health, 12(1), 14. doi:10.1186/1476-069X-12-14

Johnson, T. (2002). A guide to selected algorithms, distributions, and databases used in exposure models developed by the office of air quality planning and standards (No. CR827033). Research Triangle Park, NC: U.S. Environmental Protection Agency, Office of Research and Development.

Kang, L., \& Fricker, J. D. (2013). Bicyclist commuters' choice of on-street versus off-street route segments. Transportation. doi:10.1007/s11116-013-9453-x

Karner, A. A., Eisinger, D. S., \& Niemeier, D. A. (2010). Near-roadway air quality: Synthesizing the findings from real-world data. Environmental Science $\mathcal{E}$ Technology, 44(14), 5334-5344. doi:10.1021/ es100008x 
Kaur, S., Nieuwenhuijsen, M., \& Colvile, R. (2005). Personal exposure of street canyon intersection users to PM2. 5, ultrafine particle counts and carbon monoxide in Central London, UK. Atmospheric Environment, 39(20), 3629-3641.

Kaur, S., \& Nieuwenhuijsen, M. J. (2009). Determinants of personal exposure to PM2.5, ultrafine particle counts, and CO in a transport microenvironment. Environmental Science E Technology, 43(13), 47374743. doi:10.1021/es803199z

Kaur, S., Nieuwenhuijsen, M. J., \& Colvile, R. N. (2007). Fine particulate matter and carbon monoxide exposure concentrations in urban street transport microenvironments. Atmospheric Environment, 41(23), 4781-4810. doi:10.1016/j.atmosenv.2007.02.002

Kendrick, C., Moore, A., Haire, A., Bigazzi, A., Figliozzi, M. A., Monsere, C., \& George, L. (2011). Impact of bicycle lane characteristics on exposure of bicyclists to traffic-related particulate matter. Transportation Research Record: Journal of the Transportation Research Board, 2247, 24-32. doi:10.3141/2247-04

King, J., Unterkofler, K., Teschl, G., Teschl, S., Koc, H., Hinterhuber, H., \& Amann, A. (2011). A mathematical model for breath gas analysis of volatile organic compounds with special emphasis on acetone. Journal of Mathematical Biology, 63(5), 959-999. doi:10.1007/s00285-010-0398-9

Kingham, S., Longley, I., Salmond, J., Pattinson, W., \& Shrestha, K. (2013). Variations in exposure to traffic pollution while travelling by different modes in a low density, less congested city. Environmental Pollution, 181, 211-218. doi:10.1016/j.envpol.2013.06.030

Kingham, S., Meaton, J., Sheard, A., \& Lawrenson, O. (1998). Assessment of exposure to traffic-related fumes during the journey to work. Transportation Research Part D: Transport and Environment, 3(4), 271-274. doi:10.1016/S1361-9209(98)00005-4

Kleiner, B. C., \& Spengler, J. D. (1976). Carbon monoxide exposures of Boston bicyclists. Journal of the Air Pollution Control Association, 26(2), 147-149. doi:10.1080/00022470.1976.10470239

Knibbs, L. D., Cole-Hunter, T., \& Morawska, L. (2011). A review of commuter exposure to ultrafine particles and its health effects. Atmospheric Environment, 45(16), 2611-2622. doi:10.1016/j.atmosenv.2011. 02.065

Kumagai, S., \& Matsunaga, I. (2000). A lung model describing uptake of organic solvents and roles of mucosal blood flow and metabolism in the bronchioles. Inhalation Toxicology, 12(6), 491-510. doi:10. $1080 / 089583700402888$

Löndahl, J., Massling, A., Pagels, J., Swietlicki, E., Vaclavik, E., \& Loft, S. (2007). Size-resolved respiratory-tract deposition of fine and ultrafine hydrophobic and hygroscopic aerosol particles during rest and exercise. Inhalation Toxicology, 19(2), 109-116.

Lusk, A. C., Furth, P. G., Morency, P., Miranda-Moreno, L. F., Willett, W. C., \& Dennerlein, J. T. (2011). Risk of injury for bicycling on cycle tracks versus in the street. Injury Prevention, 17(2), 131-135.

Martin, J. C., Milliken, D. L., Cobb, J. E., McFadden, K. L., \& Coggan, A. R. (1998). Validation of a mathematical model for road cycling power. Journal of Applied Biomechanics, 14, 276-291.

McCreanor, J., Cullinan, P., Nieuwenhuijsen, M. J., Stewart-Evans, J., Malliarou, E., Jarup, L., ... Zhang, J. (2007). Respiratory effects of exposure to diesel traffic in persons with asthma. New England Journal of Medicine, 357(23), 2348-2358. doi:10.1056/NEJMoa071535

McNabola, A., Broderick, B. M., \& Gill, L. W. (2007). Optimal cycling and walking speed for minimum absorption of traffic emissions in the lungs. Journal of Environmental Science and Health. Part A, Toxic/ Hazardous Substances E Environmental Engineering, 42(13), 1999-2007.

McNabola, A., Broderick, B. M., \& Gill, L. W. (2008). Relative exposure to fine particulate matter and VOCs between transport microenvironments in Dublin: Personal exposure and uptake. Atmospheric Environment, 42(26), 6496-6512.

McNabola, A., Broderick, B. M., \& Gill, L. W. (2009a). A principal components analysis of the factors effecting personal exposure to air pollution in urban commuters in Dublin, Ireland. Journal of Environmental Science and Health, Part A: Toxic/Hazardous Substances and Environmental Engineering, 44(12), 1219-1226. doi:10.1080/10934520903139928

McNabola, A., Broderick, B. M., \& Gill, L. W. (2009b). The impacts of inter-vehicle spacing on in-vehicle air pollution concentrations in idling urban traffic conditions. Transportation Research Part D: Transport and Environment, 14(8), 567-575. doi:10.1016/j.trd.2009.08.003

Michaels, R. A., \& Kleinman, M. T. (2000). Incidence and apparent health significance of brief airborne particle excursions. Aerosol Science and Technology, 32(2), 93-105.

Nadeau, V., Truchon, G., Brochu, M., \& Tardif, R. (2006). Effect of physical exertion on the biological monitoring of exposure of various solvents following exposure by inhalation in human volunteers: I. Toluene. Journal of Occupational and Environmental Hygiene, 3(9), 481-489.

Nankervis, M. (1999). The effect of weather and climate on bicycle commuting. Transportation Research Part A: Policy and Practice, 33(6), 417-431. doi:10.1016/S0965-8564(98)00022-6 
Nawrot, T. S., Vos, R., Jacobs, L., Verleden, S. E., Wauters, S., Mertens, V., ... Vanaudenaerde, B. M. (2011). The impact of traffic air pollution on bronchiolitis obliterans syndrome and mortality after lung transplantation. Thorax, 66(9), 748-754. doi:10.1136/thx.2010.155192

Nwokoro, C., Ewin, C., Harrison, C., Ibrahim, M., Dundas, I., Dickson, I., ... Grigg, J. (2012). Cycling to work in London and inhaled dose of black carbon. European Respiratory Journal, 40(5), 1091-1097. doi:10.1183/09031936.00195711

Nyhan, M., McNabola, A., \& Misstear, B. (2014). Comparison of particulate matter dose and acute heart rate variability response in cyclists, pedestrians, bus and train passengers. Science of the Total Environment, 468-469, 821-831. doi:10.1016/j.scitotenv.2013.08.096

O’Donoghue, R. T., Gill, L. W., McKevitt, R. J., \& Broderick, B. (2007). Exposure to hydrocarbon concentrations while commuting or exercising in Dublin. Environment International, 33(1), 1-8.

Olds, T. S. (2001). Modelling human locomotion: Applications to cycling. Sports Medicine, 31(7), 497509.

Ott, W., Steinemann, A. C., \& Wallace, L. A. (2007). Exposure analysis. Boca Raton, FL: CRC Press.

Peters, A., von Klot, S., Heier, M., Trentinaglia, I., Hörmann, A., Wichmann, H. E., \& Löwel, H. (2004). Exposure to traffic and the onset of myocardial infarction. New England Journal of Medicine, 351(17), 1721-1730.

Peters, A., von Klot, S., Mittleman, M. A., Meisinger, C., Hörmann, A., Kuch, B., \& Wichmann, H. E. (2013). Triggering of acute myocardial infarction by different means of transportation. European Journal of Preventive Cardiology, 20(5), 750-758. doi:10.1177/2047487312446672

Pezzagno, G., Imbriani, M., Ghittori, S., \& Capodaglio, E. (1988). Urinary concentration, environmental concentration, and respiratory uptake of some solvents: Effect of the work load. American Industrial Hygiene Association Journal, 49(11), 546-552.

Plaut, P. O. (2005). Non-motorized commuting in the US. Transportation Research Part D: Transport and Environment, 10(5), 347-356. doi:10.1016/j.trd.2005.04.002

Pope, C. A. I., \& Dockery, D. W. (2006). Health effects of fine particulate air pollution: Lines that connect. Journal of the Air \& Waste Management Association, 56(6), 709-742.

Pucher, J. R., \& Buehler, R. (2012). City cycling. Cambridge, MA: MIT Press.

Quiros, D. C., Lee, E. S., Wang, R., \& Zhu, Y. (2013). Ultrafine particle exposures while walking, cycling, and driving along an urban residential roadway. Atmospheric Environment, 73, 185-194. doi:10.1016/j. atmosenv.2013.03.027

Ragettli, M. S., Corradi, E., Braun-Fahrländer, C., Schindler, C., de Nazelle, A., Jerrett, M., ... Phuleria, H. C. (2013). Commuter exposure to ultrafine particles in different urban locations, transportation modes and routes. Atmospheric Environment, 77, 376-384. doi:10.1016/j.atmosenv.2013.05.003

Rank, J., Folke, J., \& Homann Jespersen, P. (2001). Differences in cyclists and car drivers exposure to air pollution from traffic in the city of Copenhagen. Science of the Total Environment, 279(1-3), 131-136.

Reynolds, C. C., Harris, M. A., Teschke, K., Cripton, P. A., \& Winters, M. (2009). The impact of transportation infrastructure on bicycling injuries and crashes: A review of the literature. Environmental Health, 8(1), 47-65.

Samet, J. M. (2007). Traffic, air pollution, and health. Inhalation Toxicology, 19(12), 1021-1027. doi:10. $1080 / 08958370701533541$

Samet, J. M., Lambert, W. E., James, D. S., Mermier, C. M., \& Chick, T. W. (1993). Assessment of heart rate as a predictor of ventilation (Investigator's Report No. 59). Boston, MA: Health Effects Institute.

Sitzmann, B., Kendall, M., Watt, J., \& Williams, I. (1999). Characterisation of airborne particles in London by computer-controlled scanning electron microscopy. Science of the Total Environment, 241(1-3), 63-73. doi:10.1016/S0048-9697(99)00326-5

Steinle, S., Reis, S., \& Sabel, C. E. (2013). Quantifying human exposure to air pollution - moving from static monitoring to spatio-temporally resolved personal exposure assessment. Science of the Total Environment, 443, 184-193. doi:10.1016/j.scitotenv.2012.10.098

Strak, M., Boogaard, H., Meliefste, K., Oldenwening, M., Zuurbier, M., Brunekreef, B., \& Hoek, G. (2010). Respiratory health effects of ultrafine and fine particle exposure in cyclists. Occupational and Environmental Medicine, 67(2), 118-124. doi:10.1136/oem.2009.046847

Strauss, J., Miranda-Moreno, L., Crouse, D., Goldberg, M. S., Ross, N. A., \& Hatzopoulou, M. (2012). Investigating the link between cyclist volumes and air pollution along bicycle facilities in a dense urban core. Transportation Research Part D: Transport and Environment, 17(8), 619-625. doi:10.1016/j. trd.2012.07.007

Teschke, K., Harris, M. A., Reynolds, C. C. O., Winters, M., Babul, S., Chipman, M., .. Cripton, P. A. (2012). Route infrastructure and the risk of injuries to bicyclists: A case-crossover study. American Journal of Public Health, 102(12), 2336-2343. doi:10.2105/ AJPH.2012.300762 
Teschke, K., Reynolds, C. C. O., Ries, F. J., Gouge, B., \& Winters, M. (2012). Bicycling: Health risk or benefit? UBC Medical Journal, 3(2). Retrieved from http://prophet.library.ubc.ca/ojs/index.php/ ubcmj/article/view/2494

Thai, A., McKendry, I., \& Brauer, M. (2008). Particulate matter exposure along designated bicycle routes in Vancouver, British Columbia. Science of the Total Environment, 405(1-3), 26-35. doi:10.1016/j. scitotenv.2008.06.035

Tiwary, A., Robins, A., Namdeo, A., \& Bell, M. (2011). Air flow and concentration fields at urban road intersections for improved understanding of personal exposure. Environment International, 37(5), 1005-1018. doi:10.1016/j.envint.2011.02.006

U.S. Environmental Protection Agency. (2009). Metabolically derived human ventilation rates: A revised approach based upon oxygen consumption rates (No. EPA/600/R-06/129F). Washington, DC: Author. Retrieved from http://cfpub.epa.gov/ncea/cfm/recordisplay.cfm?deid=202543\#Download

Vallero, D. (2008). Fundamentals of air pollution (4th ed.). Burlington, MA: Elsevier Academic Press.

Van Wijnen, J. H., Verhoeff, A. P., Jans, H. W., \& Bruggen, M. (1995). The exposure of cyclists, car drivers and pedestrians to traffic-related air pollutants. International Archives of Occupational and Environmental Health, 67(3), 187-193.

Vinzents, P. S., Møller, P., Sørensen, M., Knudsen, L. E., Hertel, O., Jensen, F. P., . . Loft, S. (2005). Personal exposure to ultrafine particles and oxidative DNA damage. Environmental Health Perspectives, 113(11), 1485-1490. doi:10.1289/ehp.7562

Waldman, M., Weiss, S., \& Articola, W. (1977). A study of the health effects of bicycling in an urban atmosphere. Washington, DC: U.S. Department of Transportation. Retrieved from http://trid.trb.org/view. aspx?id $=68085$

Wallace, L. A., Nelson, W. C., Pellizzari, E. D., \& Raymer, J. H. (1997). Uptake and decay of volatile organic compounds at environmental concentrations: Application of a four-compartment model to a chamber study of five human subjects. Journal of Exposure Analysis and Environmental Epidemiology, 7(2), 141-163.

Wallace, L. A., Pellizzari, E. D., \& Gordon, S. (1993). A linear model relating breath concentrations to environmental exposures: Application to a chamber study of four volunteers exposed to volatile organic chemicals. Journal of Exposure Analysis and Environmental Epidemiology, 3(1), 75-102.

Wardman, M., Tight, M., \& Page, M. (2007). Factors influencing the propensity to cycle to work. Transportation Research Part A: Policy and Practice, 41(4), 339-350. doi:10.1016/j.tra.2006.09.011

Weichenthal, S., Kulka, R., Bélisle, P., Joseph, L., Dubeau, A., Martin, C., .. . Dales, R. (2012). Personal exposure to specific volatile organic compounds and acute changes in lung function and heart rate variability among urban cyclists. Environmental Research, 118, 118-123. doi:10.1016/ j.envres.2012.06.005

Weichenthal, S., Kulka, R., Dubeau, A., Martin, C., Wang, D., \& Dales, R. (2011). Traffic-related air pollution and acute changes in heart rate variability and respiratory function in urban cyclists. Environmental Health Perspectives, 119(10), 1373-1378. doi:10.1289/ehp.1003321

Weisman, I. M. (2003). Erratum ATS/ACCP statement on cardiopulmonary exercise testing. American Journal of Respiratory and Critical Care Medicine, 167(10), 1451-1452.

West, J. B. (2012). Respiratory physiology: The essentials (9th ed.). Baltimore, MD: Lippincott Williams \& Wilkins.

Whitt, F. R. (1971). A note on the estimation of the energy expenditure of sporting cyclists. Ergonomics, 14(3), 419-424. doi:10.1080/00140137108931261

Wilson, D. G. (2004). Bicycling science (3rd ed.). Cambridge, MA: MIT Press.

Yu, Q., Lu, Y., Xiao, S., Shen, J., Li, X., Ma, W., \& Chen, L. (2012). Commuters' exposure to PM1 by common travel modes in Shanghai. Atmospheric Environment, 59(0), 39-46. doi:10.1016/j.atmosenv. 2012.06.001

Zuurbier, M., Hoek, G., Hazel, P., \& Brunekreef, B. (2009). Minute ventilation of cyclists, car and bus passengers: An experimental study. Environmental Health, 8(1), 48-57. doi:10.1186/1476-069X-8-48

Zuurbier, M., Hoek, G., Oldenwening, M., Lenters, V., Meliefste, K., Van Den Hazel, P., \& Brunekreef, B. (2010). Commuters' exposure to particulate matter air pollution is affected by mode of transport, fuel type, and route. Environmental Health Perspectives, 118(6), 783-789.

Zuurbier, M., Hoek, G., Oldenwening, M., Meliefste, K., van den Hazel, P., \& Brunekreef, B. (2011). Respiratory effects of commuters' exposure to air pollution in traffic. Epidemiology, 22(2), 219-227.

Zuurbier, M., Hoek, G., Oldenwening, M., Meliefste, K., Krop, E., van den Hazel, P., \& Brunekreef, B. (2011). In-traffic air pollution exposure and CC16, blood coagulation, and inflammation markers in healthy adults. Environmental Health Perspectives, 119(10), 1384-1389. doi:10.1289/ehp.1003151 